DOI: 10.2478 /auseur-2020-0004

\title{
Territorial Interrelation between Innovation and a Number of Social/Infrastructural Indicators in Central and Eastern Europe (V4 + Romania) ${ }^{1}$
}

\author{
Ferenc SZILÁGYI \\ Partium Christian University, Faculty of Economics and Social Sciences, Romania \\ e-mail: ferenc.szilagyi@partium.ro \\ Edith DEBRENTI \\ Partium Christian University, Faculty of Economics and Social Sciences, Romania \\ e-mail: debrenti.edit@partium.ro
}

\begin{abstract}
The study examines the performance of the Visegrád countries and Romania. As an indicator of innovation performance, we used the number of researchers measured from the active population. Due to the large variations in the size of the administrative-territorial units, the use of this ratio seems more adequate than using absolute values. The innovation indicator and the other indicators used are included in the analysis database in a regional breakdown. All indicators have an overview map of the entire large region for the purpose of establishing the territorial profile. In the course of the statistical investigation, each indicator was individually compared to the innovation index.
\end{abstract}

Keywords: Visegrád countries, innovation, social indicators, correlation, regression

\section{Introduction, Sources, Research Area}

The Global Competitiveness Report of the Year $2019^{2}$ and the article ${ }^{3}$ on the Visegrád Countries based on the report which appeared in March 2020 state that 'the real gap between competitiveness and innovation is rather within the EU. In particular,

1 The study and the database are part of a research project funded by the IRP - Institute of Research Programmes, Sapientia Hungarian University of Transylvania, entitled The Effect of the Exchange Rate Volatility on the Tourism of Central and Eastern European Countries.

2 http://www3.weforum.org/docs/WEF_TheGlobalCompetitivenessReport2019.pdf.

3 https://visegradinsight.eu/whither-innovation-in-the-v4/?fbclid=IwAR03cA811G51vtH1Xem5 0TYAh--lqlqTrjosats1Z8EEAnCLfHrT3vVzmD8. 
Central Europe lacks world-class academic institutions.' The study concludes that: 'This yawning gap is between the EU's four most competitive economies and the laggards, consisting of the V4, the rest of Central Europe and most of Southern Europe.' However, this study does not examine the gap between the Western and Eastern EU Member States but rather whether the group of East-Central European States (CEEC) can be considered a homogenous territory. The question arises as to what extent the V4 and Romania form a homogenous macro-region in Europe. To examine this, we used innovation and some general socio-economic indicators. The secondary question of the research is whether a connection can be detected between innovation and the indicators used.

The study investigates the performance of the V4 and Romania based on EUROSTAT and national statistical institutes' yearbooks and databases (Czech Republic - CSO, ${ }^{4}$ Poland - GUS, ${ }^{5}$ Hungary - KSH, ${ }^{6}$ Romania - INSSE, ${ }^{7}$ and Slovakia $\left.-\mathrm{SOSR}^{8}\right)$ :

- Data on the Czech Republic were taken from the Comparison of Regions in the Czech Republic - 20179 yearbook published in January 2018 and the Regional Yearbooks $-2017^{10}$ series.

- Polish data were taken from the Statistical Yearbook of the Regions - Poland $2017^{11}$ and the Road Transport in Poland - 2014-15 $5^{12}$ yearbooks.

-Data on Hungary come from the Statistical Yearbook of Hungary $2016^{13}$ published in the fall of 2017, the Yearbook of Regional Statistics 2015, ${ }^{14}$ the Household Living Standards $2016^{15}$ yearbook as well as the KSH STADAT online database (3.4.2. ${ }^{16}$ and 6.3.4.1. ${ }^{17}$ Research development places).

- Data on Romania, given the lack of a current regional yearbook, were taken from the TEMPO ONLINE ${ }^{18}$ database.

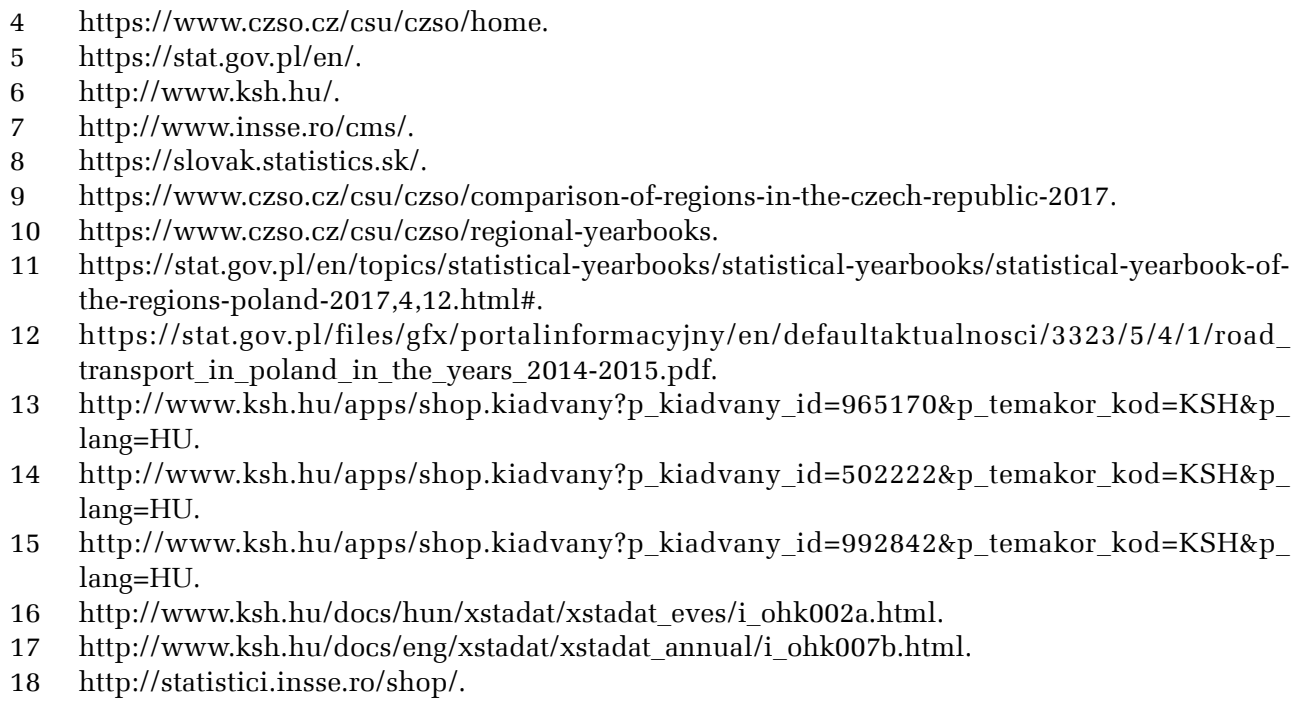


- Data on Slovakia were taken from the Statistical Yearbook of the Slovak Republic 2017, the Regional Statistical Yearbook of Slovakia 2017, and the Our Regions 2017 publications. Data on certain infrastructures come from the National Regional Development Strategy of the Slovak Republic, while comparative data for the research come from the Yearbook of Science and Technology in the Slovak Republic 2014.

Air traffic data were taken from the Airport Traffic Report $2017^{19}$ of the ACI (Airport Council International) Europe, while GDP data were taken from the EUROSTAT Data Explorer NUTS3-level online database ${ }^{20}$ (nama_10r_3gdp).

\subsection{Indicators, Aims, Method}

Chosen index: the ratio of researchers in the active population serves as the index of innovation performance. Given the significant differences in size of the territorial units, using a ratio is more justified than the absolute value. This value, of course, only partially represents innovation performance. We have chosen this index because relatively current data were readily available for each Member State, broken down to larger territories.

We used the following indicators in the comparison:

- social indicators: population density and the ratio of university students (thousandths);

- economic indicators: the 2015 GDP value, 2016 gross salaries, and the number of vehicles per 1,000 inhabitants;

- infrastructural indicators: road density (higher category roads - motorways, expressways, national roads, secondary roads, regional/county roads), motorway density, railway density, ratio of air passengers in the population.

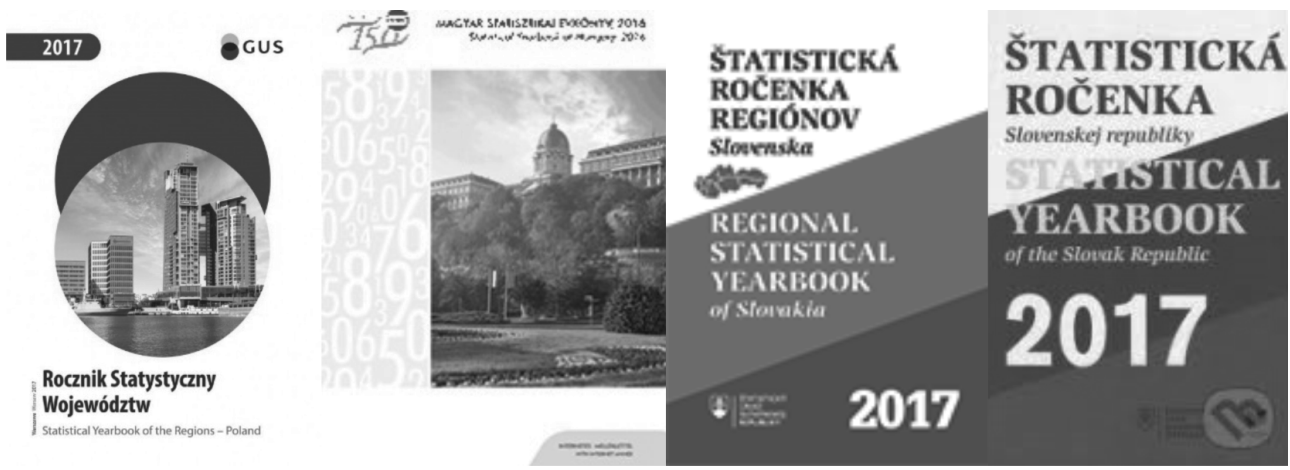

Figure 1. Some of the statistical sources used in the analysis

19 https://www.aci-europe.org/policy/position-papers.html?view=group\&group=1\&id=11

20 http://appsso.eurostat.ec.europa.eu/nui/show.do?dataset=nama_10r_3gdp\&lang=en. 
The bulk of the statistical data was taken from the 2017 regional yearbooks of national statistical institutes or, in the absence of these (in the case of Romania), from the online database of the statistical institute. The GDP data converted into euros was taken from the EUROSTAT database. Data from the national institutes are from 2016, while GDP data from the EUROSTAT database are from 2015. This one-year difference does not pose a problem since when calculating correlation or regression a coherent, homogeneous database is more important than the simultaneity of the data compared.

Comparing data from national databases was often problematic. The Polish statistical yearbook presents territorial data on the level of voivodeships, which correspond to NUTS2-level territorial units, while territorial units in the other countries are NUTS3 level, and the data are also provided on this level. To ensure a larger territorial breakdown, we have chosen country level (NUTS3) in the case of four countries (CZ, HU, RO, SK), while in the case of Poland we have chosen the level of voivodeships (NUTS2).

Matching different categories also posed problems, e.g., in the infrastructure. Voivodeship-level roads in Poland do not correspond entirely to the middlecategory roads in the other countries under scrutiny. Thus, in such cases, territorial differences can be pointed out by closely following state borders.

\subsection{The Course of Investigation}

The innovation index and the indicators were introduced into the database, broken down by territory. In order to establish a territorial profile, a comprehensive map for the metropolitan region was created for each indicator. During the statistical investigation, we compared each indicator individually to the innovation index and calculated descriptive statistics, correlation, and regression with Excel Data Analysis. At the end of the analysis, we also did a joint regression calculation with R-program in order to investigate to what extent joint indicators account for the innovation index.

\section{Ratio of Scientific Researchers in the Active Population}

2.1. Situation in the $E U$ : In 2017, three clusters could be distinguished in the ranking of the proportion of R\&D personnel and researchers in the EU Member States: the highest proportions were measured in the northern and western European Member States (9 Member States), medium values mainly in the southern Member States (9 Member States), and the lowest proportions were measured in the 10 new Member States. The two best-performing new Member States are already in the middle cluster (Slovenia and the Czech Republic). In reality, the biggest differences can 
be measured among the laggards. For instance, three members of the V4 (Poland, Hungary, and Slovakia) rank next to each other $\left(20^{\text {th }}-22^{\text {nd }}\right.$ places $)$. In their case, the average of the examined indicator is $1.32 \%$, which is half the average of the 9 states in the first cluster $(2.58 \%)$ but 2.6 times higher than the average of Romania, their cluster member. The statistical distance is smaller between the first and the twentieth than between the twentieth and the twenty-eighth places (Fig. 2). This propounds the question whether Central and Eastern European Countries (CEEC) can be listed in the same cluster.

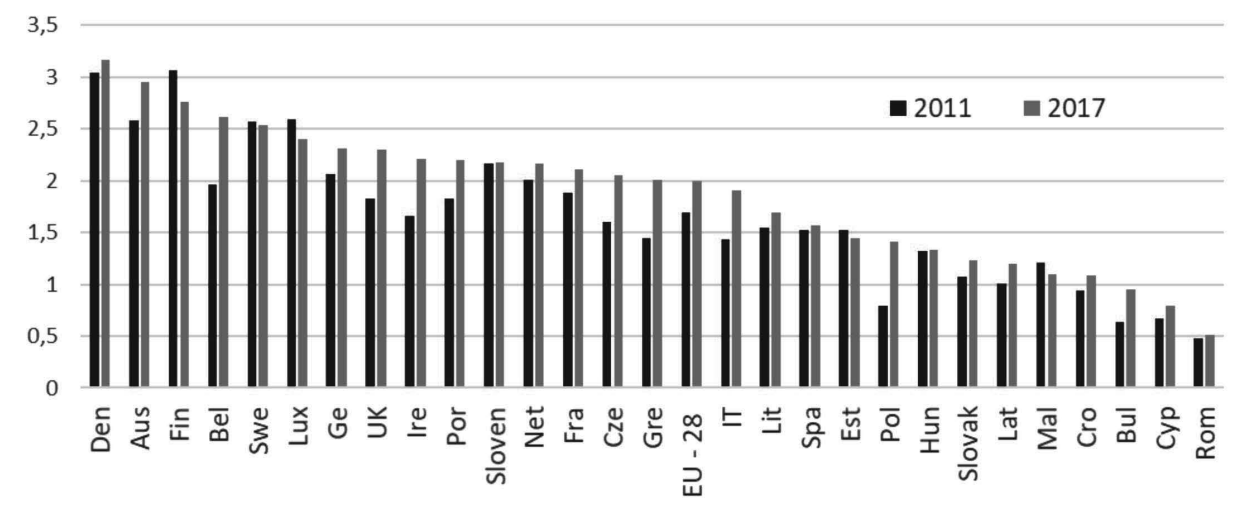

Source: Eurostat, rd_p_perslf

Figure 2. Total R\&D personnel and researchers by sectors of performance, as \% of total labour force

2.2. Researchers in countries + Romania: If we examine only the number of researchers in the five countries, we get a completely different order than in the case of the previous, more complex indicator. According to the national statistical offices, the population of the V4 + Romania $\left(771,246 \mathrm{~km}^{2}\right)$ was 83,572,171 in 2016 . In the same year, the number of researchers was 244,527 , which represents $5.6 \%$ of the more than 43.3 million active population. The ratio of researchers in the five countries differs significantly. The ratio is the highest in Slovakia (9\%) and Hungary (8.4\%o), followed by the Czech Republic (7\%o). The two most populated countries of the region, Poland and Romania, are lagging behind (5.1\%o and 3.7\%o, respectively). ${ }^{21}$ This latter ratio is far behind the regional average, and even in absolute terms it precedes only Slovakia, the smallest country in the region. As regards absolute numbers, Poland's leading position is unquestionable, with $45.7 \%$ of the total number of researchers.

21 The ratio of the active population in the total population reveals a different pattern. In 2016, this ratio was pre-eminent in Poland (57.7\%). It was also slightly above $50 \%$ in Slovakia and the Czech Republic (50.7\%, 50.6\%), while in Hungary it was only $46.6 \%$ and $44.2 \%$ in Romania. The 2016 microcensus provides a higher value (4.754 mil. people; 48.4\%: https://www.ksh. hu/docs/hun/xftp/idoszaki/mikrocenzus2016/mikrocenzus_2016_5.pdf) than the data from the KSH STADAT database (4.5859 mil.). 
2.3. Territorial profile: For each country, the capital region shows outstanding values (usually above 10\%o). Bratislava and Budapest stand out with $33.8 \%$ and $26.3 \%$, respectively, and the value for Prague remains slightly below $20 \%$. The case of Romania is slightly anomalous since the moderate value of Bucharest $(11.3 \%)$ is significantly exceeded by the surrounding suburban Ilfov County (21.3\%o). Given its large size, the capital region of Poland (Masovia) tempers the values of the capital (10.5\%). In the Czech Republic and Hungary, distinctive regional extremes can also be identified (Csongrád 13.9\%o, Southern Moravia 13.5\%, Hajdú-Bihar 10.4\%o, Baranya $9.1 \%$ ) connected to larger regional universities. Given the large size of administrative units, similar universities are less contrasting in Poland and Slovakia (Košice 9\%o, Lesser Poland 8.4\%o). The bulk of Slovakia's territory ranges between $5 \%$ and $10 \%$ (5 counties), presenting a rather uniform distribution. In the other countries under scrutiny, these values surface in conglomerates and show a better performance than the average value (Lower Silesia, Pomerania - PL; Olomouc, Plzen - CZ; Veszprém, Győr-Moson-Sopron - HU; Timiş, Sibiu, Argeş, Iaşi - RO). In 2016 , in 25 administrative units in the area under scrutiny, the ratio of researchers did not amount to $1 \%$ of the active population. One such administrative unit lies in Hungary (Békés - 0.9\%o), one in the Czech Republic (Karlovy Vary 0.7\%o), and 23 in Romania, where they form large, connected areas, specifically in the east and south (Fig. 3). In 2016, the ratio of researchers could not be measured in four administrative units in Romania (Botoşani, Ialomița, Mehedinți, Olt). In Poland, presumably the large unit size (NUTS2) does not provide an appropriate breakdown for detecting marked territorial differences.

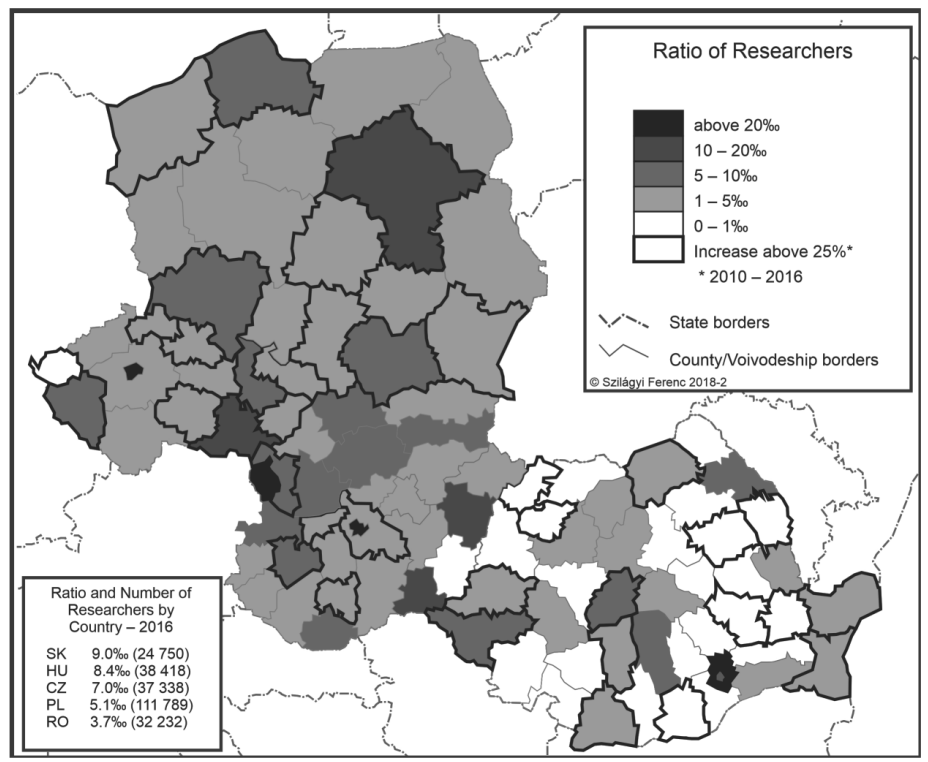

Figure 3. Ratio of scientific researchers in the active population 
2.4. Changes 2010-2016: During the investigation period, countries with a lower ratio of researchers accomplished a very spectacular growth. In Poland, the number of researchers saw a $37 \%$ increase within six years. However, the $28 \%$ increase in the Czech Republic and $23 \%$ in Romania can also be considered spectacular. In Hungary, the increase was only $9 \%$, while in Slovakia we can speak of stagnation (3\%). 39 administrative units saw a more than 25\% increase (17 RO. 9 CZ. 8 PL. 4 HU. 1 SK). It needs to be pointed out, though, that seven Romanian and one Czech unit are from those where the ratio of researchers did not reach 1\% in 2016. Consequently, the increase in absolute terms is rather low in these cases. Between 2010 and 2016, the most spectacular increase took place in the Romanian Sibiu County (800\%, from 180 researchers to 1,622). Olomouc, Plzen, Liberec, Vysočina, and Southern Moravia in the Czech Republic, Veszprém in Hungary, Ilfov and Dolj in Romania, and Lesser Poland, Lower Silesia, and Pomerania in Poland are the leading territories. 12 Romanian and 4 Hungarian units saw a more than $25 \%$ decrease in the number of researchers. If we disregard the subratio of below $1 \%$, we are left with four Hungarian (Szabolcs-Szatmár-Bereg 39\%, Jász-Nagykun-Szolnok 31\%, Győr-Moson-Sopron, and Borsod-Abaúj-Zemplén 27\%) and three Romanian counties (Galați 46\%, Hunedoara 42\%, and Braşov 28\%).
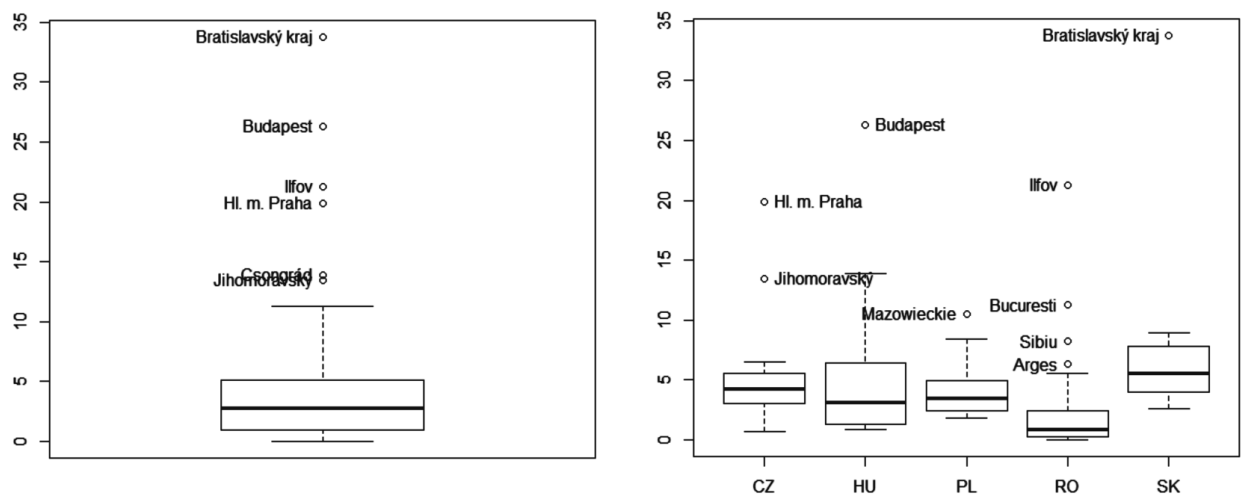

Figure 4. The ratio of researchers (\%o)

On the level of metropolitan regions, the median of the ratio of researchers is $3 \%$, and the average is $4.14 \%$. The upper quartile is $5 \%$, while the maximum values are slightly above $10 \%$. The six outlier data are connected mostly to the capital regions and the most powerful provincial centres (Brno, Szeged). 


\section{Social Indicators}

\subsection{Population Density}

According to our hypothesis, population density has an indirect effect on the chosen innovation index since the presence of an appropriate 'critical mass' is necessary.

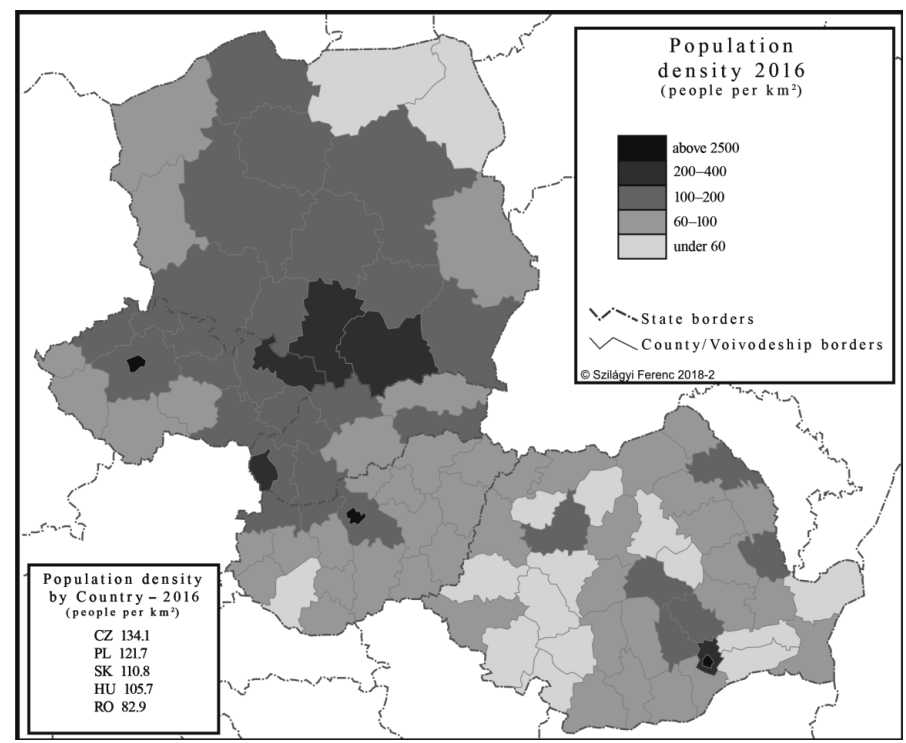

Figure 5. Population density by country - 2016

General data: The total area of the five countries in Central and Eastern Europe is $771,246 \mathrm{~km}^{2}, 17.1 \%$ of the territory of the EU, and the total population is $83,572,171$ inhabitants, $16.3 \%$ of the EU population. It follows that the population density of the area does not differ drastically from the EU average (108.5 inhabitants $/ \mathrm{km}^{2}$ as compared to 114.4 inhabitants $/ \mathrm{km}^{2}$ ). The Czech Republic has the highest population density $^{22}$ (134.1), followed by Poland (121.7), even though after World War II these two countries suffered a significant loss of population, which has only been partly compensated for (or at least on the regional level). The two smallest countries in the area in terms of population (Slovakia and Hungary) boast of a population density nearing the metropolitan region average. The population density of the two countries has changed since 1980, with a point of intersection around $1990 .{ }^{23}$ Romania stands

22 The maximum population density in the Czech Republic was registered in 1940. The current population number corresponds to the 1928 level (see: https:/www.czso.cz/csu/czso/ population_hd). Contrary to this, the population of Poland is increasing at an incredible rate. By 1970, it had already reached the number before World War II and surpassed it significantly (see: http://www.cicred.org/Eng/Publications/pdf/c-c43.pdf). http://www.worldometers.info/world-population/slovakia-population/. 
alone in the third group (Fig. 5) with the lowest value (82.9 inhabitants $/ \mathrm{km}^{2}$ ), which, in addition, is experiencing a sharply declining trend.

Territorial profile: The extremely high values surface in conglomerates in the leading administrative units. The highest values can be detected where the administrative border is immediately adjacent to the border of the capital (Bucharest 7,753 inhabitants $/ \mathrm{km}^{2}$; Budapest 3,351; Prague 2,580). In Bratislava, where the suburban area is part of the administrative unit, the value is much lower (313), while Warsaw as part of the large Masovian Voivodeship (149.7) does not make a perceptible difference in the Polish area. Bucharest and Budapest exerting an influence on their immediate environment perceptibly increase the value of Ilfov and Pest counties (280 and 193 respectively). Disregarding the prominent nodules, it is certain that the demographic centre of gravity of the metropolitan region is the eastern Pre-Sudeten, Silesia, and Lesser Poland (Silesia 366; Moravian-Silesian 223, Lesser Poland 220). Territories with a population density higher than 100 inhabitants $/ \mathrm{km}^{2}$ form a cohesive area in the central and southern parts of Poland, the east of the Czech Republic, the whole of Moravia, western Slovakia, and the middle and north-west of Hungary. In Romania, this category is present only as a conglomerate; it forms a larger cohesive area in the economic centre of the country, between Bucharest and Braşov, and surfaces in the form of smaller regions among some significant economic extremities (Cluj, Iaşi, Galați). At the other end of the hierarchy, we find territorial units with a population density lower than 60 inhabitants $/ \mathrm{km}^{2}$. Apart from three of them (Somogy - HU and two voivodeships in north-east Poland), these form larger blocks in Romania (13 units). The least inhabited administrative unit in the metropolitan region is Tulcea county (23.9 inhabitants $/ \mathrm{km}^{2}$ ), which also incorporates the Danube Delta.

Table 1. Population density and the ratio of researchers in the active population show moderate correlation

\begin{tabular}{|c|c|c|c|c|c|c|c|c|}
\hline \multicolumn{2}{|c|}{ Regression Statistics } & & \multirow[t]{2}{*}{ ANOVA } & \multirow[b]{2}{*}{$d f$} & \multirow[b]{2}{*}{ SS } & \multirow[b]{2}{*}{ MS } & \multirow[b]{2}{*}{$F$} & \multirow[b]{2}{*}{ Significance $F$} \\
\hline Multiple R & 0.391175 & & & & & & & \\
\hline R Square & 0.153018 & & Regression & 1 & 439.436678 & 439.436678 & 17.705026 & 0.000057 \\
\hline Adjusted R Square & 0.144375 & & Residual & 98 & 2432.348459 & 24.819882 & & \\
\hline Standard Error & 4.981955 & & Total & 99 & 2871.785138 & & & \\
\hline \multirow[t]{2}{*}{ Observations } & 100 & & & & & & & \\
\hline & Coefficients & Standard Error & $t$ Stat & P-value & Lower 95\% & Upper $95 \%$ & Lower $95.0 \%$ & Upper $95.0 \%$ \\
\hline Intercept & 3.574839 & 0.516281 & 6.924212 & 4.605942E-10 & 2.550296 & 4.599382 & 2.550296 & 4.599382 \\
\hline Density & 0.002440 & 0.000579 & 4.207734 & 0.000057 & 0.001289 & 0.003591 & 0.001289 & 0.003591 \\
\hline
\end{tabular}

Statistical results: Population density and the ratio of researchers in the active population show moderate correlation $(\mathrm{R}=0.39)$. The $\mathrm{p}$-value is below 0.05, wherefore the alternative hypothesis is valid; there is significant (essential, detectable) correlation between the variables (Table 1). 


\subsection{Ratio of University Students}

Given the close relationship between research and higher education, a significant correlation is expected between the ratio of researchers in the active population and the ratio of university students in the total population. In the case of the latter, the number of students was identified according to the location of the university, not according to the students' place of birth/living.

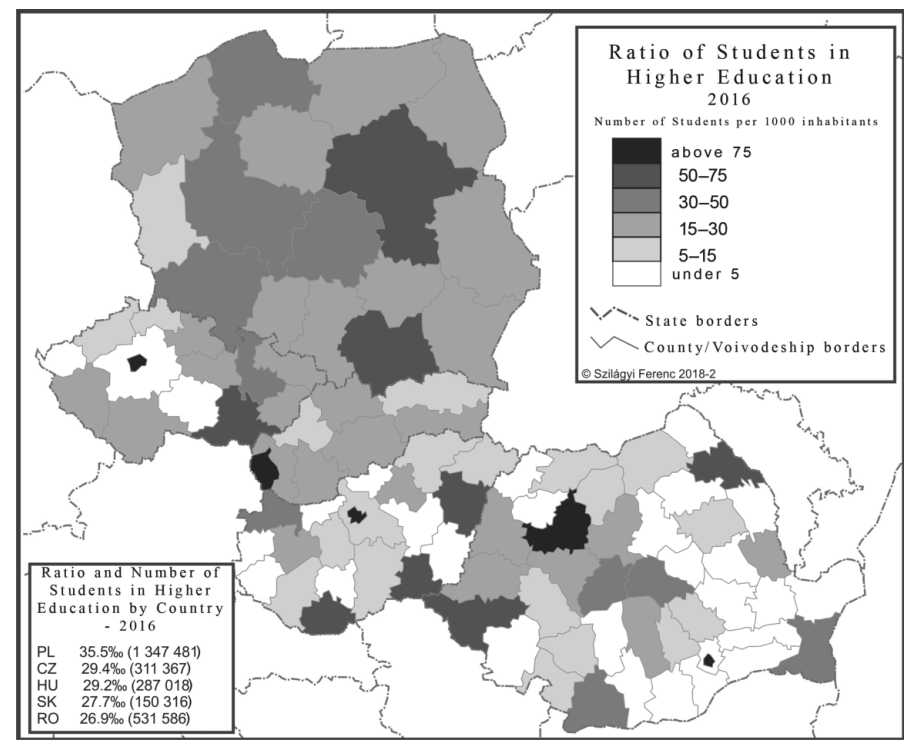

Figure 6. Ratio of students in higher education by county - 2016

General data: In 2015, the number of students in the region was $3,094,600,{ }^{24}$ which represents $15.8 \%$ within the European Union. This is about half a percent less than the region's population ratio in the EU. According to the national statistical institute's data, the number of students in 2016 was 2,627,768. This means that the number of students per 1,000 inhabitants in 2016 in the metropolitan region was 31.44. Only in Poland did the number of students exceed the average value (35.5\%). About half of the university students in Central and Eastern Europe are recorded to be in Poland. The Czech Republic and Hungary (29.4-29.2\%) are close to the average, with a very similar value, while Slovakia $(27.7 \%$ ) and Romania $(26.9 \%)$ are lagging behind in this respect.

Territorial profile: Due to the size of territorial units in Poland and Slovakia, we can speak of a relatively balanced distribution (Fig. 6). The former is characterized by average and relatively high values, while Slovakia is characterized by the uniformity

24 http://ec.europa.eu/eurostat/statistics-explained/images/8/8b/Number_of_tertiary_education_ students_by_level_and_sex\%2C_2015_\%28thousands\%29_YB17.png 
of average values. In the case of the other three countries, the smaller unit size gives rise to more significant contrasts. All three are characterized by extremes. Large university centres stand out from their less developed environment as beacons of science. In some cases, the vacuum effect applies: a prominent centre is surrounded by counties with a specifically low value. This phenomenon is also present in the Czech Republic and Hungary, but it is specific to the eastern and southern parts of Romania, in the area of Bucharest, Iaşi, and Craiova. The number of students per 1,000 inhabitants is prominent, especially in capital units. However, the highest value in the Central and Eastern Europe region was registered not in a capital unit but in the Romanian Cluj County, with a 95.9 value. This is followed by four capital regions: Bucharest (93.3), Prague (92.5), Bratislava (88.9), and Budapest (81.3). Due to the extended Masovia region, the Polish capital is again an exception, and it fits into the second group of administrative units (50.7), preceded by several regional centres such as: Iaşi (67.4), Timişoara (57.9), Southern Moravia (56.8), Csongrád (56.1), Baranya (54), Hajdú-Bihar (51.2), and even Lesser-Poland voivodeships overtakes it (50.8). 29 administrative units lag behind with a value below 5: three in the Czech Republic, six Hungarian, and 20 Romanian administrative units. Since statistical data rely on the location of the institutions and do not consider extensions, 10 administrative units, which lack autonomous institutions, figure with the value 0 in the database.

Table 2. The ratio of university students in the population and the ratio of researchers show significant correlation

\begin{tabular}{|c|c|c|c|c|c|c|c|c|}
\hline \multicolumn{2}{|c|}{ Regression Statistics } & & \multirow[t]{2}{*}{ ANOVA } & \multirow[b]{2}{*}{$d f$} & \multirow[b]{2}{*}{ SS } & \multirow[b]{2}{*}{ MS } & \multirow[b]{2}{*}{$F$} & \multirow[b]{2}{*}{ Significance $F$} \\
\hline Multiple R & 0.691567 & & & & & & & \\
\hline R Square & 0.478265 & & Regression & 1 & 1373.475527 & 1373.475527 & 89.83497 & 1.643609E-15 \\
\hline Adjusted R Square & 0.472941 & & Residual & 98 & 1498.309610 & 15.288873 & & \\
\hline Standard Error & 3.910098 & & Total & 99 & 2871.785138 & & & \\
\hline \multirow[t]{2}{*}{ Observations } & 100 & & & & & & & \\
\hline & Coefficients & Standard Error & t Stat & $P$-value & Lower 95\% & Upper 95\% & Lower $95,0 \%$ & Upper $95,0 \%$ \\
\hline Intercept & 0.588500 & 0.541914 & 1.085967 & 0.280157 & 0.486910 & 1.66391 & 0.486910 & 1.663911 \\
\hline Student ratio \%o & 0.163753 & 0.017276 & 9.478131 & 1.643609E-15 & 0.129467 & 0.198038 & 0.129467 & 0.198038 \\
\hline
\end{tabular}

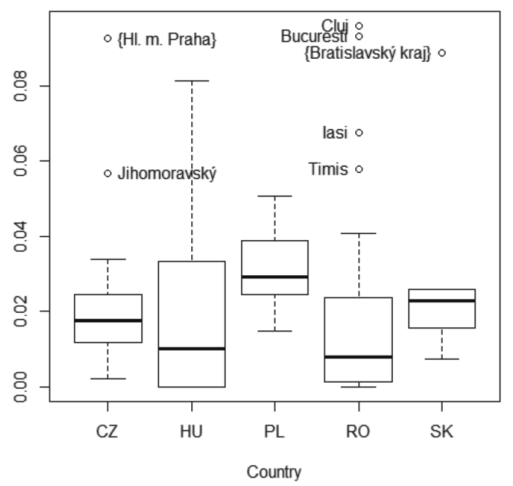


Statistical results: As expected, the ratio of university students in the population and the ratio of researchers in the active population show significant correlation (Table 2). The $\mathrm{R}^{2}$ value is 0.48 . The $\mathrm{p}$-value is very low.

\section{Economic Indicators}

\subsection{GDP - 2015}

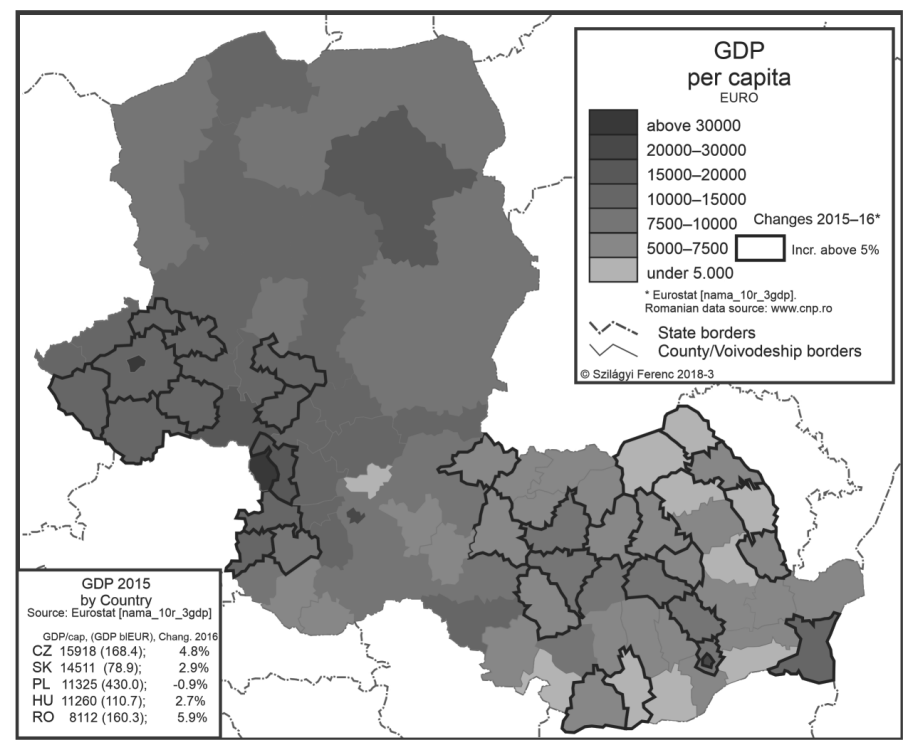

Figure 7. GDP by county - 2015

General data: In 2015, the European Union GDP was 14,797.444 billion euros. The five Central and Eastern European countries investigated had a share of 948.4 billion euros. This amounted to a bare $6.4 \%$ of the total EU GDP in 2015. It follows that the average GDP per capita in the EU is 28,861 euros, while in the investigated region the value is only 11,350 euros. The performance of two countries out of the five significantly exceeds this average value (the Czech Republic: close to 16,000 $€$ and Slovakia: 14,500 €), two countries are close to the regional average (Poland, Hungary), and one country is way behind (Romania: 8,112 €). Comparing the 2015 and 2016 national statistical institutes' data, we find that in this period there was an outstanding increase in two countries (Romania: $5.9 \%$ and the Czech Republic: $4.8 \%$ ), a moderate increase in two countries (Slovakia: $2.9 \%$ and Hungary: $2.7 \%$ ), and a slight decline in one of the countries (Poland: $0.9 \%$ ). In this period, the total EU GDP increased by $2.2 \%$. 
Territorial profile: Polish voivodeships exhibit the narrowest GDP range while the Hungarian and Romanian units the widest one. The GDP value of the weakest units in the Czech Republic and Slovakia are around the Polish median, slightly exceeding the Hungarian median, and significantly exceeding the Romanian one. The capital units in each country figure as outliers. The most outstanding ones are Bratislava and Prague (Fig. 7). The only outlier which is not a capital unit is GyőrMoson-Sopron in Hungary (Kónya 2019). In 2015, the 30,000 € value was exceeded only by the capital region of the two most developed countries (Bratislava: 35,532 $€$ and Prague: $34,680 €$ ), and the 20,000 € value was exceeded also by two capitals (Budapest: 22,945 and Bucharest: 21,457). The Masovia value of the Polish capital is again more tempered $(17,497 €)$, only slightly exceeding the value of the Czech Republic. In the case of the Czech Republic, the GDP of all NUTS3 territorial units exceeds 10,000 €/capita, and from the provincial units Southern Moravia alone reaches 15,000. The situation is similar in Slovakia, where Trnava County exhibits an outstanding value; however, the value of Prešov County is significantly below 10,000 €/capita. In Poland, 5 voivodeships exceed the 10,000 threshold, while nine do not reach it. In Hungary, only four counties reach it (Győr-Moson-Sopron, Fejér, Komárom-Esztergom, Vas), one from the remaining 15 counties (Nógrád is below 5,000 ), while other five remain below 7,500 €/capita. In Romania, only two counties (Timiş and Constanța) reach the 10,000 threshold, while in nine counties (in eastern and southern Romania) the 5,000 value is only a theoretical target. The poorest counties in the region are Vaslui and Botoşani, where the GDP per capita in 2015 was below 4,000 euros.

In 2015, not less than 36 administrative units generated a higher than $5 \%$ increase (19 in Romania). The record holder is the Romanian Prahova County with a 25\% increase; however, other five Romanian counties (Constanța, Galați, Olt, Cluj, and Hunedoara) generated an increase of at least 10\%. In the Czech Republic, there were seven such territorial units, in Hungary four, and in Slovakia one. In the calendar year of the investigation, 13 administrative units saw recession, with the highest rate in Zala County in Hungary.

Statistical results: As expected, the 2015 GDP value per capita and the ratio of researchers in the active population show significant correlation (Table 3). The $\mathrm{R}^{2}$ value is 0.58 , higher than in the case of the social indicators. The p-value is insignificant. 
Table 3. The 2015 GDP value per capita and the ratio of researchers in the active population show significant correlation

\begin{tabular}{|c|c|c|c|c|c|c|c|c|}
\hline \multicolumn{2}{|c|}{ Regression Statistics } & & ANOVA & \multirow[b]{2}{*}{$d f$} & \multirow[b]{2}{*}{ SS } & \multirow[b]{2}{*}{ MS } & \multirow[b]{2}{*}{$F$} & \multirow[b]{2}{*}{ Significance $F$} \\
\hline Multiple R & 0.767635 & & & & & & & \\
\hline R Square & 0.589264 & & Regressior & 1 & \multicolumn{4}{|c|}{$1692.24211692 .2421140 .596591 .2067471 \mathrm{E}-20$} \\
\hline Adjusted R Square & 0.585073 & & Residual & 98 & \multicolumn{3}{|c|}{1179.543012 .036153} & \\
\hline Standard Error & 3.469315 & & Total & 99 & \multicolumn{2}{|c|}{2871.785138} & & \\
\hline Observations & 100 & & & & & & & \\
\hline & Coefficients & Standard Error & $t$ Stat & P-value & \multicolumn{3}{|c|}{ Lower 95\% Upper 95\%ower 95.0\% } & Upper $95.0 \%$ \\
\hline Intercept & -3.562622 & 0.736801 & \multicolumn{6}{|c|}{${ }^{\prime}-4.8352544 .933586 E^{\prime}-5.024781^{\prime}-2.100464^{\prime}-5.024781^{\prime}-2.100464$} \\
\hline GDP eur 2015 & 0.000814 & 0.000068 & 11.857343 & $1.206747 \mathrm{E}$ & 0.000678 & 0.000950 & 0.000678 & 0.000950 \\
\hline
\end{tabular}

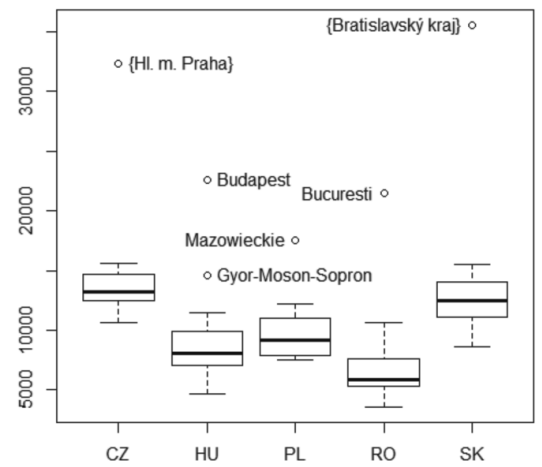

\subsection{Gross Average Salaries}

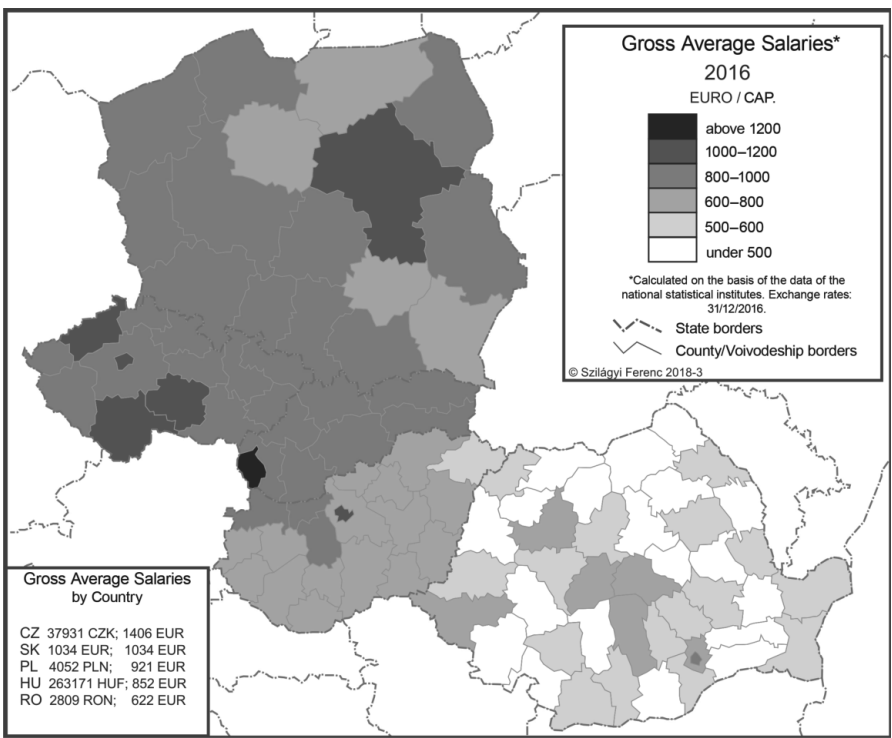

Figure 8. Gross average salaries - 2016 
General data: It is an indicator at the intersection of economic performance, national law, and tax and wage policy. National traits are very powerful; there are relatively clear dividing lines between the countries of the region. There are significant differences on a national level. The multiplier between the highest (the Czech Republic: $1406 €$ ) and the lowest (Romania: $622 €$ ) rate of pay is 2.3. The countries between the two extreme values are relatively evenly distributed. The smallest gap is between the third and fourth position on the list (Poland and Hungary).

Territorial profile: One can delimit three larger territorial units in the Central and Eastern European region. The borders of these territories are relatively closely tied to the position of state borders (Fig. 8). The boxplot analysis of individual countries indicates little overlap. For example, the lowest values in the Czech Republic are higher than the high values in Hungary. On the level of individual countries, the widest range surfaces in Hungary while the narrowest in the Czech Republic, where the territorial values are relatively even. The outliers on the high end of the distribution are generated by capital cities. In Romania, Ilfov, Cluj, and Timiş counties are also prominent. Low-value outlier is recorded only in the Czech Republic (Morava-Silesia). Regarding territorial breakdown, the large northern part is in the best position (with values typically exceeding $800 €$ ). It covers the Czech Republic and Slovakia completely, most of Poland, and the northeast corner of Hungary (Győr-Moson-Sopron, Fejér, Komárom-Esztergom). The region has seven administrative units where the gross average salary exceeded 1,000 $€$ in 2016.

Among these were four capital regions (Bratislava: $1356 €$, Masovia: 1124, Budapest: 1101, and Prague: 1087), followed by three administrative units in the Czech Republic (Vysočina, Jihočeský, and Ústecký). The second area, with values ranging between 600 and $800 €$, covers the rest of Hungary (except SzabolcsSzatmár-Bereg County) and crosses the eastern boundary of the country only to include Timiş County in Romania. The third area, with values below $600 €$, covers most of Romania, where four prospering areas stand out: Bucharest-Ilfov, SibiuBraşov-Argeş, Cluj, and Timiş. At the bottom of the list, we find the counties where the gross average salary was below $500 €$. These are 19 in number, and all of them are located in Romania. The last two on the list in the metropolitan regions are the two Szekler-Hungarian-inhabited counties: Harghita: $463 €$ and Covasna: $470 €$.

Statistical results: As expected, the 2016 gross average salary and the ratio of researchers in the active population show significant correlation (Table 4). The 0.38 $\mathrm{R}^{2}$, however, indicates a moderate value. The $\mathrm{p}$-value is insignificant. 
Table 4. The 2016 gross average salary and the ratio of researchers in the active population show significant correlation

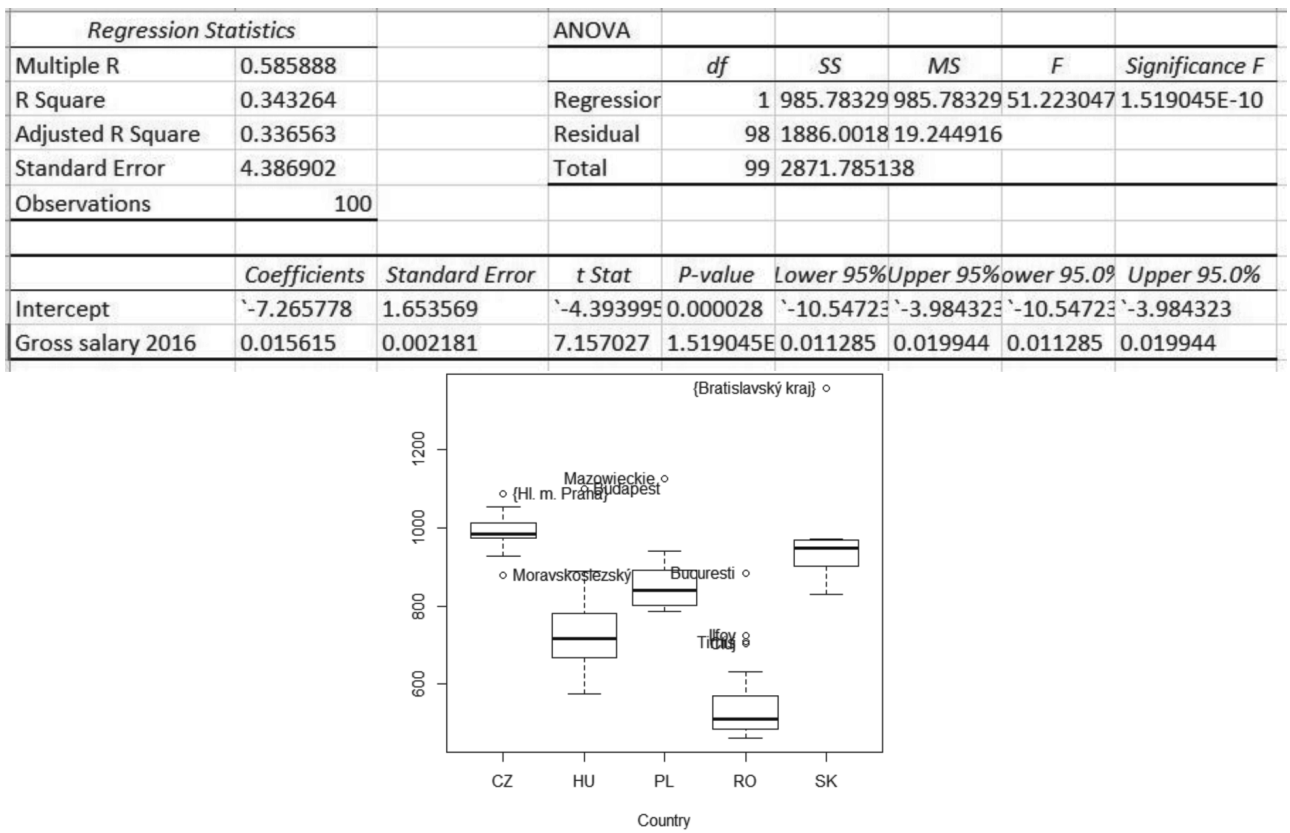

\section{Infrastructural Indicators}

\subsection{Road Network, Number of Vehicles}

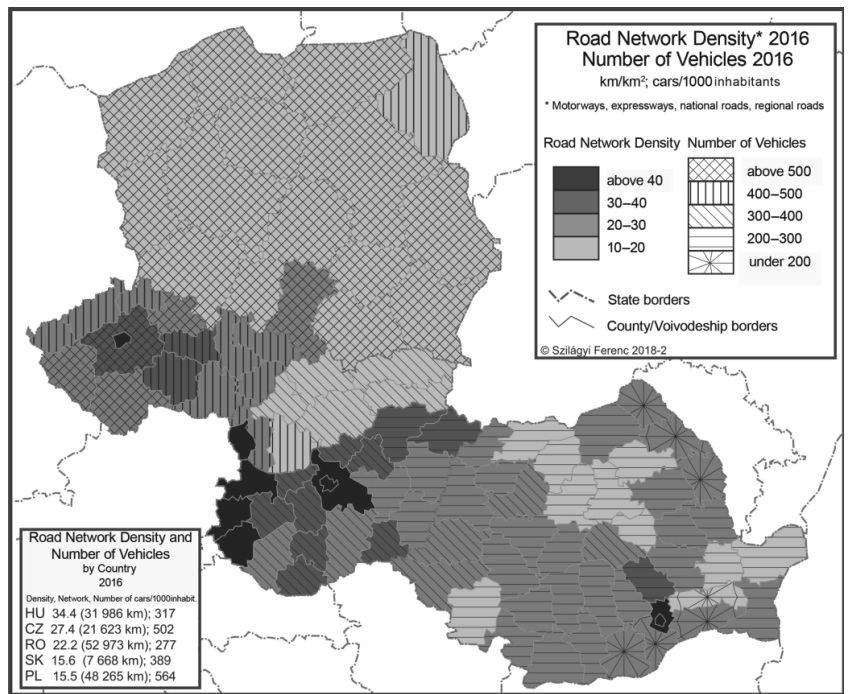

Figure 9. Road network density and number of vehicles by county - 2016 
General data: When considering the overall development of the infrastructure and innovation performance, we dedicated attention to the correlation of the general road network and the motorway network in particular (see Chapter 5.2). Network density is influenced by many factors. There are significant differences between the five countries. These may arise from the overall level of development of the infrastructure, geographical features as well as regional networks, administrative and legal characteristics. In the case of Slovakia and some parts of Romania, the low network density can be ascribed to geographical features. In our analysis, we considered highercategory road networks (motorways, expressways, national roads) and mediumcategory road networks (voivodeship roads, county roads). Obviously, the mediumcategory road network in Poland, where the territorial units are large, falls short of the medium-category road network in Hungary, where the administrative territorial units are much smaller. The absolute value indicates the longest road networks in Romania and Poland (52,973 $\mathrm{km}$ and 48,265 $\mathrm{km}$ respectively). In the middle range, we find Hungary and the Czech Republic, while the road network in Slovakia shows a shortfall $(7,668 \mathrm{~km})$. In terms of road network density, the leaders are Hungary $(34.4$ $\mathrm{km} / 100 \mathrm{~km}^{2}$ ) and the Czech Republic (27.4), followed by a mediocre value in Romania (22.2) and low values in Slovakia and Poland (15.6-15.5). It should be noted that the analysis does not consider the type and quality of roads. No further distinction is made between medium-category roads. If we consider the number of passenger cars per 1,000 inhabitants, we get completely different results. Poland immediately jumps the line and takes the leading position; together with the Czech Republic they both exceed the value of 500 (Poland: 564, Czech Republic: 502). Slovakia achieves a medium value (389), while Hungary (317) and Romania (277) a lower one.

Territorial profile: The highest (above $40 \mathrm{~km} / 100 \mathrm{~km}^{2}$ ) road density category, apart from capital cities, among provincial units is present only in the western Hungarian Vas, Zala, and Győr-Moson-Sopron counties as well as in Pest County and in Romania in Ilfov County surrounding the capital (Fig. 9). Values above the average, ranging between 30 and 40 are characteristic of ten Hungarian counties (five Transdanubian, four in the north of Hungary, and Csongrád), three counties in the centre of the Czech Republic, and one Romanian administrative unit (Prahova). Low-medium road density (20-30) is characteristic of the rest of Hungary and the Czech Republic, most parts of Romania, except some counties in the mountains and in the southeast, Trnava in Slovakia, and Upper Silesia in Poland. The lowest density category comprises almost all of Poland, six counties in Slovakia, and ten Romanian units. At the end of the line in the metropolitan region, there are Tulcea County, which encompasses the Danube Delta, and Podlaskie Voivodeship in Poland (11.3-11.1). Hungarian counties present the widest range, while the narrowest range can be found in the Polish voivodeships with their low values.

The territorial distribution of the vehicle fleet per 1,000 inhabitants is unique in the sense that there is not a clear dominance of capital cities even though Prague 
is at the top of the list in the metropolitan region (648). Masovia comes third; however, many Polish voivodeships have similarly high values. Bratislava comes sixth, Bucharest is $14^{\text {th }}$, while Budapest (348) is the $47^{\text {th }}$ in the region's ranking. All Polish voivodeships, except one, exceed the value of $500 .{ }^{25}$ The same high value is characteristic of 5 units in the Czech Republic. Values ranging between 400 and 500 are characteristic of the rest of the Czech Republic and Poland as well as western Slovakia. Values between 300 and 400 can be found in the rest of Slovakia, twothirds of western Hungary, and in Romanian counties with the most developed infrastructure (Arad, Timiş, Cluj, Braşov). In the eastern counties of Hungary and most parts of Romania, the typical value is below 300; what is more, in seven counties in the east and south of Romania, the value is below 200. The lowest values can be found in Călăraşi in the south (153) and Vaslui in the east (156).

Statistical results: Road density and the ratio of researchers in the active population do not show significant correlation (Table 5). There is no point in using this indicator in the study. The p-value also exceeds $5 \%$, and the role of coincidence cannot be excluded. The data of vehicles per 1,000 inhabitants indicates small correlation.

Table 5. Road density $\left(\mathrm{km} / 100 \mathrm{~km}^{2}\right)$ and the number of vehicles per 1,000 inhabitants

\begin{tabular}{|c|c|c|c|c|c|c|c|c|}
\hline \multicolumn{2}{|c|}{ Regression Statistics } & & ANOVA & \multirow[b]{2}{*}{$d f$} & \multirow[b]{2}{*}{ SS } & \multirow[b]{2}{*}{ MS } & \multirow[b]{2}{*}{ 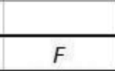 } & \multirow[b]{2}{*}{ Significance $F$} \\
\hline Multiple R & 0.060991 & & & & & & & \\
\hline R Square & 0.003719 & & Regressior & 1 & \multicolumn{3}{|c|}{10.68297310 .6829730 .365918} & 0.546635 \\
\hline Adjusted R Square & -0.006446 & & Residual & 98 & \multicolumn{3}{|c|}{2861.102129 .194920} & \\
\hline Standard Error & 5.403232 & & Total & 99 & \multicolumn{2}{|c|}{2871.785138} & & \\
\hline Observations & 100 & & & & & & & \\
\hline & Coefficients & Standard Error & t Stat & P-value & \multicolumn{3}{|c|}{ Lower 95\% Upper 95\%ower $95.0 \%$} & Upper $95.0 \%$ \\
\hline Intercept & 3.163317 & 1.710102 & 1.849782 & 0.067358 & \multicolumn{2}{|c|}{$-0.2303256 .556959$} & \multicolumn{2}{|c|}{$-0.2303256 .556959$} \\
\hline Road density & 0.040487 & 0.066931 & 0.604912 & 0.546635 & \multicolumn{2}{|c|}{$-0.0923350 .173309$} & \multicolumn{2}{|c|}{$-0.0923350 .173309$} \\
\hline
\end{tabular}

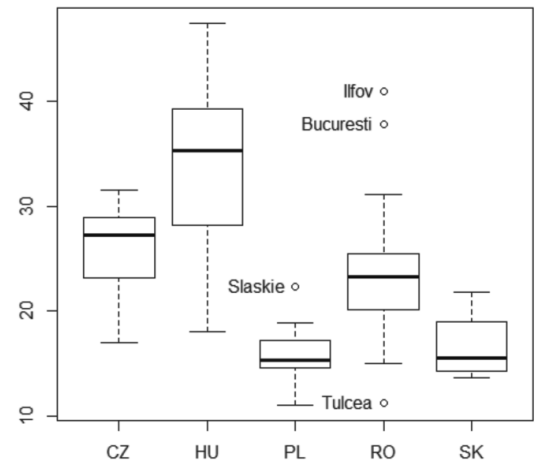

25 The EU average presents similar values: http://ec.europa.eu/eurostat/statistics-explained/index. php?title=Stock_of_vehicles_at_regional_level\#Regional_characteristics_within_the_EU. 


\begin{tabular}{|c|c|c|c|c|c|c|c|c|}
\hline \multicolumn{2}{|c|}{ Regression Statistics } & & \multirow[t]{2}{*}{ ANOVA } & \multirow[b]{2}{*}{$d f$} & \multirow[b]{2}{*}{ SS } & \multirow[b]{2}{*}{ MS } & \multirow[b]{2}{*}{$F$} & \multirow[b]{2}{*}{ Significance $F$} \\
\hline Multiple R & 0.345309 & & & & & & & \\
\hline R Square & 0.119238 & & Regression & 1 & 342.428351 & 342.428351 & 13.267396 & 0.000433 \\
\hline Adjusted R Square & 0.110251 & & Residual & 98 & 2529.356786 & 25.809763 & & \\
\hline Standard Error & 5.080331 & & Total & 99 & 2871.785138 & & & \\
\hline \multirow[t]{2}{*}{ Observations } & 100 & & & & & & & \\
\hline & Coefficients & Standard Error & $t$ Stat & P-value & Lower $95 \%$ & Upper $95 \%$ & Lower $95.0 \%$ & Upper $95.0 \%$ \\
\hline Intercept & -0.984534 & 1.497046 & -0.657651 & 0.512304 & -3.955375 & 1.986306 & -3.955375 & 1.986306 \\
\hline \multicolumn{2}{|c|}{ No of vehicles $/ 1,000$ inha 0.014156} & 0.003886 & 3.642443 & 0.000433 & 0.006443 & 0.021869 & 0.006443 & 0.021869 \\
\hline
\end{tabular}

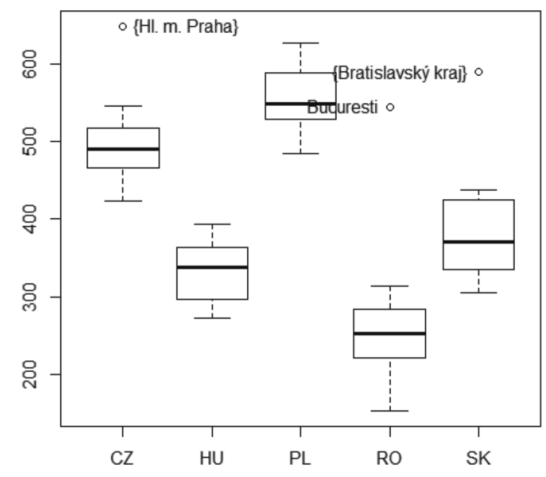

\subsection{Motorway and Expressway Network Density}

Since the previous infrastructural indicator did not lead to relevant results, we looked into the expressway network and carried out the measurements.

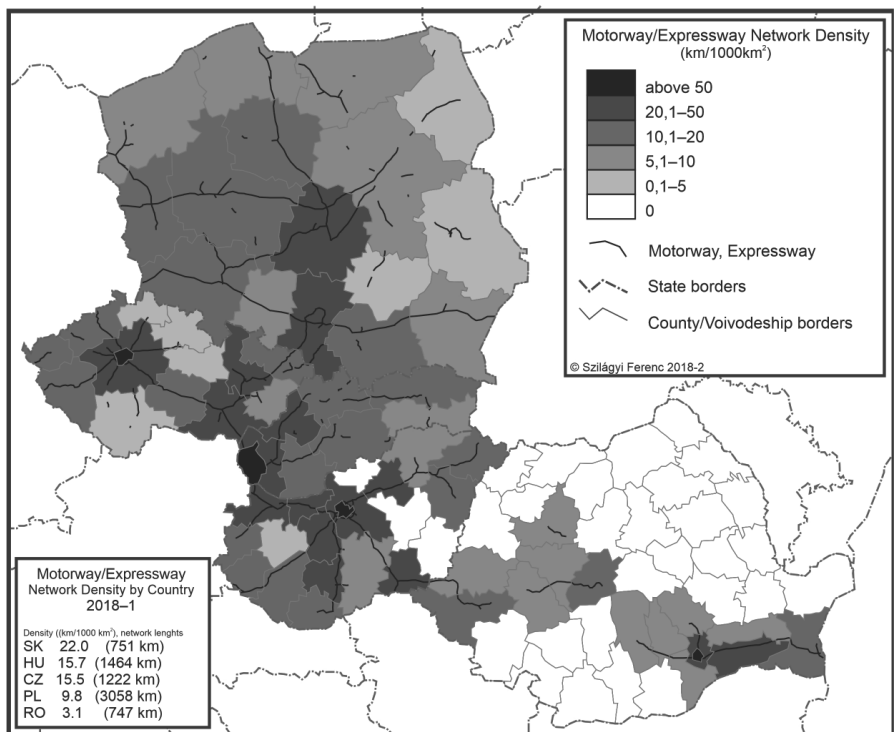

Figure 10. Motorway/expressway network density by country - 2018-1 
General data: ${ }^{26}$ In 2016, the length of the motorway and expressway network in the European Union was $76,416 \mathrm{~km}$. The region investigated comprises less than $10 \%$ of this. Thus, the network is underrepresented on the Union level. Considering the rate of increase, however, this seems to be the fastest developing region on the EU level. In 2005, the network was only one third of its size and represented less than $5 \%$ of the EU network. All countries investigated, except Romania, have made incredible progress in the past two decades and managed to complete a more or less connected network, sometimes reaching to the borders of the countries. Apart from Bucharest, all capital cities are directly connected to the European motorway network. As regards the absolute length of the network, Poland's leading position is unquestionable $(3,058 \mathrm{~km})$. Hungary and the Czech Republic are in the middle category, while Slovakia and the much larger Romania are lagging behind. By 2018, Slovakia took over the leading position in terms of network density $\left(22 \mathrm{~km} / 1,000 \mathrm{~km}^{2}\right)$, leaving Hungary and the Czech Republic behind. Polish values are moderate, while the Romanian data is only one seventh of the Slovakian one (3.1).

Territorial profile: The centre of gravity of the metropolitan region is the area of Bratislava (Fig. 10). The territories with high network density cover the northwest and central part of Hungary, west Slovakia, most of Moravia, Silesia, and Lódz Voivodeship. The priority of capital cities is straightforward with this indicator as well. All four territories with high (above 50) values belong to this category. Prague $\left(90.7 \mathrm{~km} / 1,000 \mathrm{~km}^{2}\right)$, Bucharest, and Budapest are leading with a very similar value, followed by Bratislava. The concept behind the network also has an effect on the territorial distribution of density. In Hungary, the concept is building from the centre outwards; there are/were hardly any independent sections, while in Poland, the Czech Republic, and Slovakia these are very characteristic. As a result, in the latter countries, there are no administrative units completely lacking networks. Certain sections were built early as bypass roads in the vicinity of administrative centres, even when the motorway had not yet reached the area. In contrast, in Hungary, there are still blank spots, counties in which the motorway network density was statistically zero at the beginning of 2018 (Nógrád, Szolnok, Békés). ${ }^{27}$ The odd one out is Romania with not less than 27 counties in which the motorway network is statistically zero.

Statistical results: As expected, the motorway network density in 2016 and the ratio of researchers in the active population show significant correlation (Table 6). The $\mathrm{R}^{2}$ value is 0.5 . The $\mathrm{p}$-value is insignificant.

26 http://ec.europa.eu/eurostat/web/products-datasets/-/ttr00002.

27 In 2018, construction was ongoing in all three cases: M4 from Albertirsa to Abony, M44 and Road 21 are extended to four lanes, and there are certain sections (e.g. on Road 4) which function as motorways though they are not officially listed as such. 
Table 6. The motorway network density $\left(\mathrm{km} / 1,000 \mathrm{~km}^{2}\right)$ in 2016 and the ratio of researchers show significant correlation

\begin{tabular}{|c|c|c|c|c|c|c|c|c|}
\hline \multicolumn{2}{|c|}{ Regression Statistics } & & ANOVA & \multirow[b]{2}{*}{$d f$} & \multirow[b]{2}{*}{ SS } & \multirow[b]{2}{*}{$M S$} & \multirow[b]{2}{*}{$F$} & \multirow[b]{2}{*}{ Significance $F$} \\
\hline Multiple R & 0.707412 & & & & & & & \\
\hline R Square & 0.500432 & & Regressior & & \multicolumn{4}{|c|}{$1437.13321437 .133298 .1695021 .916226 \mathrm{E}-16$} \\
\hline Adjusted R Square & 0.495334 & & Residual & 98 & \multicolumn{3}{|c|}{1434.651814 .639304} & \\
\hline Standard Error & 3.826134 & & Total & 99 & \multicolumn{2}{|c|}{2871.785138} & & \\
\hline Observations & 100 & & & & & & & \\
\hline & Coefficients & Standard Error & $t$ Stat & $P$-value & \multicolumn{3}{|c|}{ Lower 95\% Upper 95\%ower 95.0\% } & Upper $95.0 \%$ \\
\hline Intercept & 1.399445 & 0.472405 & 2.962380 & 0.003830 & 0.461971 & 2.336920 & 0.461971 & 2.336920 \\
\hline \multicolumn{2}{|c|}{ Motorway network de 0.227884} & 0.022999 & 9.908052 & $1.916226 \mathrm{E}-16$ & 0.182241 & 0.273527 & 0.182241 & 0.273527 \\
\hline
\end{tabular}

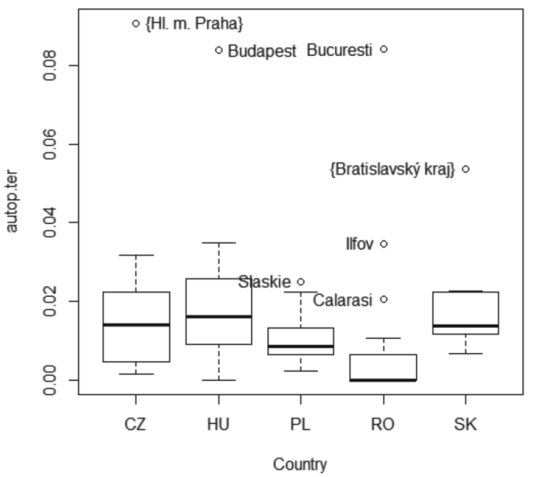

\subsection{Railway Network Density}

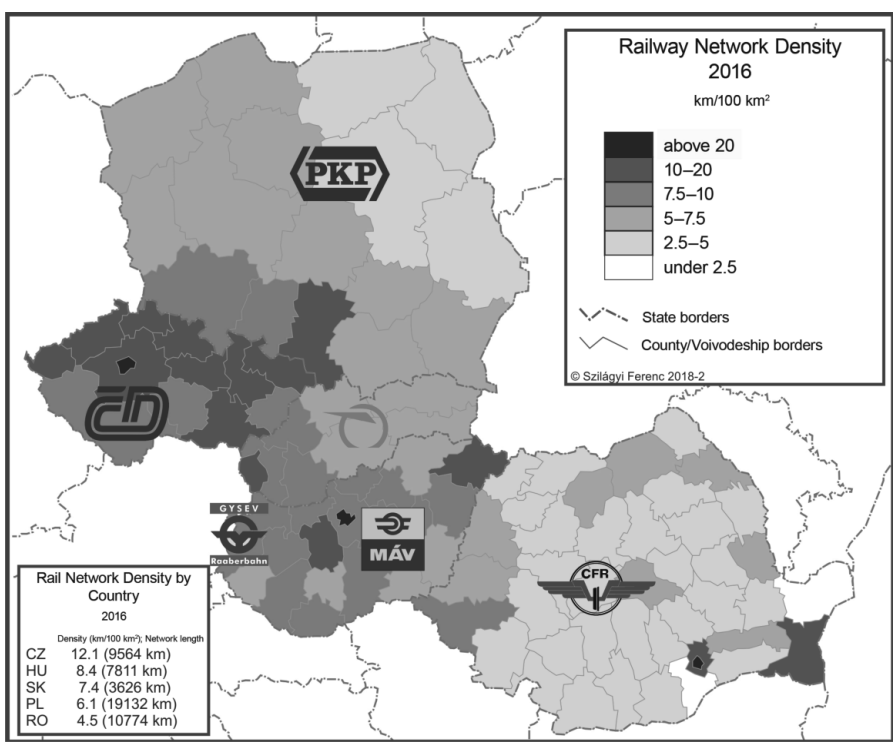

Figure 11. Rail network density by country - 2016 
General data: The EU network length in 2016 was $325,904 \mathrm{~km}$ with a density of $72.8 \mathrm{~km} / 1,000 \mathrm{~km}^{2}$. The network length of the five Central and Eastern European countries was $50,907 \mathrm{~km}, 15.6 \%$ of the EU network. In terms of network density, the region $\left(66 \mathrm{~km} / 1,000 \mathrm{~km}^{2}\right)$ is close to the EU average; however, in terms of double tracks, electrified lines, speed and quality of services, there is a huge discrepancy. In terms of total track length, the countries in the region occupy a prominent position even in global rankings. Not considering microstates and city-states, the rail line density of the Czech Republic comes third globally and second within the EU. Globally speaking, Hungary, Romania, and Slovakia are also in the top 10, and Poland is only about 5 positions behind. If we investigate the countries in the region not in terms of tracks but in terms of length of rail lines, then, of course, in terms of absolute value - given its vast territory - Poland comes first (19,132 km), followed by Romania $(10,774 \mathrm{~km})$ and the Czech Republic $(9,564 \mathrm{~km})$. Hungary $(7,811 \mathrm{~km})$ and Slovakia bring up the rear $(3,626 \mathrm{~km})$. In terms of line network density, the Czech Republic stands out above all the others $\left(121 \mathrm{~km} / 1,000 \mathrm{~km}^{2}\right)$, Hungary and Slovakia occupy the middle position (84 and 74 respectively), while Poland (61) and Romania (45) are lagging behind.

Territorial profile: Within the metropolitan region, the Czech Republic, more specifically the northern part of the country and Moravia, represents the network density centre of gravity (Fig. 11). This high density rail line area extends over to Polish Silesia and the northern part of Slovakia, which connects with the not prominent but relatively high and evenly distributed Hungarian values. Most of Poland is characterized by medium and low values, with a decreasing trend towards the northeast, Central and Eastern Slovakia as well as most of Romania, where we can find clusters of counties with more favourable conditions. In the ranking of administrative units, three capital cities emerge with a very high value (Prague, Budapest, and Bucharest: $400-475 \mathrm{~km} / 1,000 \mathrm{~km}^{2}$ ), followed by administrative units mostly from the Czech Republic. Bratislava County is the $13^{\text {th }}$, Ilfov, the Romanian unit with the highest network density, is the $14^{\text {th }}$, while Fejér County, the Hungarian unit with the highest density, occupies the $17^{\text {th }}$ position. At the end of the ranking containing 101 entries, the 22 administrative units with a value below 40 are almost all in Romania, except the Polish Podlaskie. Tulcea and Giurgiu are at the end of the list with the lowest values (12 and 13).

Statistical results: As expected, the railway network density in 2016 and the ratio of researchers in the active population show significant correlation (Table 7). The $\mathrm{R}^{2}$ value is 0.3 . The $\mathrm{p}$-value is insignificant. 
Table 7. The railway network density $\left(\mathrm{km} / 1,000 \mathrm{~km}^{2}\right)$ in 2016 and the ratio of researchers show significant correlation

\begin{tabular}{|c|c|c|c|c|c|c|c|c|}
\hline \multicolumn{2}{|c|}{ Regression Statistics } & & \multirow[t]{2}{*}{ ANOVA } & \multirow[b]{2}{*}{$d f$} & \multirow[b]{2}{*}{ SS } & \multirow[b]{2}{*}{ MS } & \multirow[b]{2}{*}{$F$} & \multirow[b]{2}{*}{ Significance $F$} \\
\hline Multiple R & 0.551092 & & & & & & & \\
\hline R Square & 0.303702 & & \multicolumn{2}{|l|}{ Regressior } & \multicolumn{2}{|c|}{872.16910872 .169} & \multicolumn{2}{|c|}{$42.7444922 .828011 \mathrm{E}-09$} \\
\hline Adjusted R Square & 0.296597 & & Residual & 98 & \multicolumn{3}{|c|}{1999.616020 .404245} & \\
\hline Standard Error & 4.517105 & & Total & 99 & \multicolumn{2}{|c|}{2871.785138} & & \\
\hline Observations & 100 & & & & & & & \\
\hline & Coefficients & Standard Error & t Stat & P-value & \multicolumn{4}{|c|}{ Lower 95\% Upper 95\%ower $95.0 \%$ Upper $95.0 \%$} \\
\hline Intercept & 0.797638 & 0.682747 & 1.168276 & 0.245529 & \multicolumn{2}{|c|}{$-0.5572512 .152528$} & \multicolumn{2}{|c|}{$-0.5572512 .152528$} \\
\hline Railway network de & 0.417842 & 0.063910 & 6.537927 & $2.828011 \mathrm{E}$ & E 0.291013 & 0.544670 & 0.291013 & 0.544670 \\
\hline
\end{tabular}

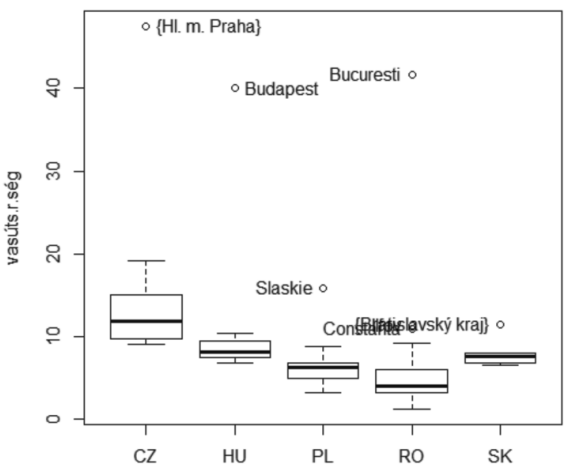

\subsection{Air Traffic}

The last decade has witnessed an explosive growth. Central and Eastern European countries have seen a boom partly due to the emergence and success of low-cost airlines. These, of course, include the market leader Western European airlines, but the success of local airlines has also actively contributed to the achievement (Wizzair, Blueair). The extension of the leading airports in the region stands out globally as well. Traffic records are broken year after year, often with a double-digit growth. The leading airports in the region are nearing their capacity limits in many respects. Further expansion is a question of investment capacity and willingness.

General data: On a global level, the USA and China are the biggest players in air transport. If we consider the traffic of airlines according to home country, their annual traffic is 800 million and 436 million passengers respectively. Countries following them are way behind. The biggest European player is Great Britain, third on the list, Germany is fourth, and Ireland is sixth, all having a traffic exceeding 100 million. Among the emerging countries, Hungary, due to Wizzair, occupies the $31^{\text {st }}$ place globally and a leading position in the region. The achievement of regional airlines is much more divergent. Hungary and Slovakia currently do not have a regional airline. The Romanian Tarom has been loss-making since 2008, 
and its survival is questionable..$^{28}$ The regional airline in the Czech Republic is smaller than Tarom, and its achievement is better but unsteady. The biggest regional airline in the region is the Polish LOT, which has even extended in the past few years, establishing several HUBs in the region and introducing many new flights, including intercontinental ones. When investigating the air traffic of individual countries, we have to take into consideration the fact that the catchment area of large airports extends across borders and that there are some HUB airports close to the countries investigated (Berlin, Munich, Vienna), which attract a significant number of passengers from the countries in this study, thus reducing the traffic of airports located within the country. The total traffic of the airports in the region cannot be considered weightless. In 2017, it amounted to 92.6 million passengers. ${ }^{29}$ Almost half of this can be assigned to Poland (43.5\%), Romania, the Czech Republic, and Hungary are between $2 \%$ and $14 \%$, while Slovakia contributes less than $3 \%$.

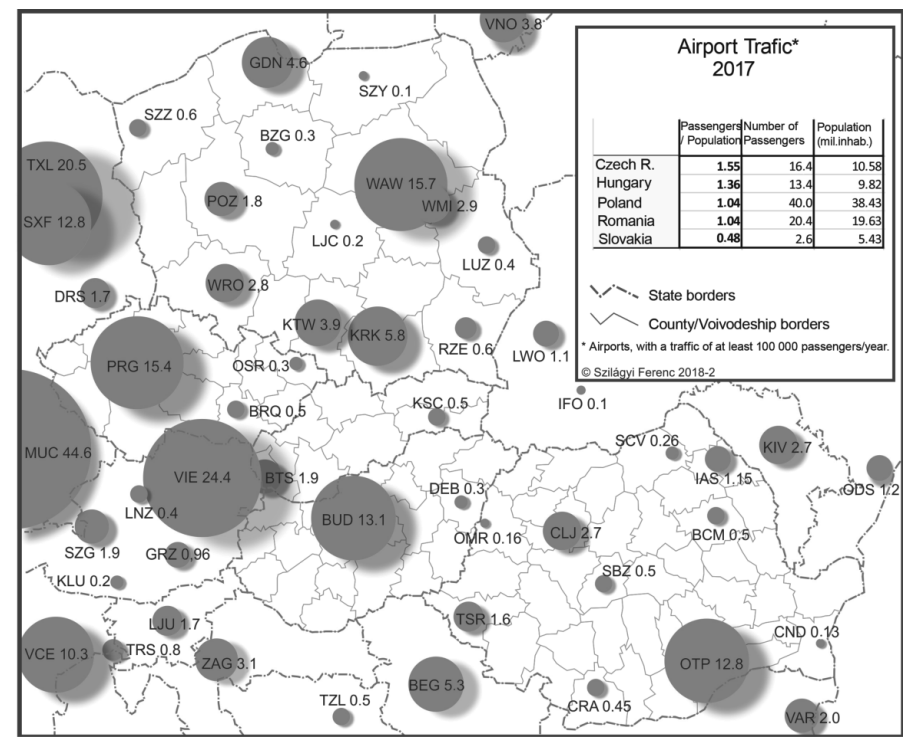

Figure 12. Airport traffic - 2017

Territorial profile: In 2017, in 29 cities in the region, there were 30 international airports with a traffic exceeding 100,000 passengers per year (Fig. 11). The analysis does not include airports with traffic below the threshold (e.g. Sármellék, Poprad, Tárta, Satu Mare, etc.) or airports which were closed in 2017 for renovation or

28 https://www.digi24.ro/stiri/economie/transporturi/romania-furata-tarom-o-companienationala-lasata-in-voia-sortii-de-toate-guvernarile-742377; https://seenews.com/news/ romanias-tarom-expects-2017-loss-of-207-mln-lei-45-mln-euro-transport-min-589564.

29 The data are based on international airports with traffic of more than 100,000 passengers per year. 
expansion (e.g. Târgu-Mureş). The traffic of these airports was provisionally taken over by adjacent airports. Each of the 29 cities with international airports is located in a separate administrative unit, which means that 71 out of the 100 units in the region do not operate a significant airport. 12 out of the 29 units are located in Poland, nine in Romania, three in the Czech Republic, while Hungary and Slovakia have two each. Given the large administrative units in Poland, only four voivodeships remain without an airport; in Slovakia, there are six units, in the Czech Republic ten, in Hungary 17, and in Romania 32 units without an airport. ${ }^{30}$ There are more cities with two national airports, but in 2017 only in Warsaw did both airports have significant traffic (Warsaw - Chopin: 15.7 mil. passengers; Warsaw - Modlin: 2.9 mil. passengers). In terms of traffic, four capital city airports stand out from the 30 units in the region. The 2017 ACI report lists these within the same category, Group 2 of European airports (annual traffic: between 10 and 25 million passengers). According to the December 2017 data, Prague is the $35^{\text {th }}$, Warsaw the $36^{\text {th }}$, Budapest Ferihegy 2 the $39^{\text {th }}$, while Bucharest occupies the $43^{\text {rd }}$ position, with values close to each other. Only the airport in Krakow belongs to Group 3 (between 5 and 10 million passengers per year), all the remaining airports belonging to Group 4. There are significant differences within the group since due to their traffic of over 1 mil. passengers 9 units are important regional airports: Gdansk, Katowice, Warsaw Modin, Wroclaw, Cluj, Bratislava, Poznan, Timişoara, and Iaşi. Smaller airports have a local catchment area or are extending to one or two adjacent units.

Statistical results: As expected, the airport traffic in 2017 and the ratio of researchers in the active population show significant correlation (Table 8 ). The $\mathrm{R}^{2}$ value is 0.37 . The $\mathrm{p}$-value is insignificant.

Table 8. The airport traffic in 2017 and the ratio of researchers show significant correlation

\begin{tabular}{|c|c|c|c|c|c|c|c|c|}
\hline \multicolumn{2}{|c|}{ Regression Statistics } & & ANOVA & \multirow[b]{2}{*}{$d f$} & \multirow[b]{2}{*}{ SS } & \multirow[b]{2}{*}{ MS } & \multirow[b]{2}{*}{$F$} & \multirow[b]{2}{*}{ Significance $F$} \\
\hline Multiple R & 0.613633 & & & & & & & \\
\hline R Square & 0.376545 & & Regressior & 1 & \multicolumn{4}{|c|}{ 1081.3581 1081.3581 59.188729 1.1371527E-11 } \\
\hline Adjusted R Square & 0.370183 & & Residual & 98 & \multicolumn{3}{|c|}{1790.426918 .269663} & \\
\hline Standard Error & 4.274302 & & Total & 99 & \multicolumn{2}{|c|}{2871.785138} & & \\
\hline Observations & 100 & & & & & & & \\
\hline & Coefficients & Standard Error & t Stat & P-value & \multicolumn{3}{|c|}{ Lower 95\% Upper 95\%ower 95.09 } & Upper $95.0 \%$ \\
\hline Intercept & 2.752290 & 0.464173 & 5.929443 & $4.560880 \mathrm{E}$ & 1.831153 & 3.673427 & 1.831153 & 3.673427 \\
\hline Air passengers/pop. & 2.453285 & 0.318880 & 7.693421 & 1.137152E & 1.820476 & 3.086094 & 1.820476 & 3.086094 \\
\hline
\end{tabular}

30 Due to the location of the capital city airports, we considered the following as units with airport: in Hungary - Budapest and Pest County, in the Czech Republic - Prague and Central Bohemia, and in Romania - Bucharest and Ilfov. 


\section{Conclusions}

The study investigates the performance of the V4 and Romania based on EUROSTAT and national statistical institutes' yearbooks and databases. The ratio of researchers in the active population serves as the index of innovation performance. This value, of course, only partially represents innovation performance.

We used the following indicators in the comparison:

- social indicators: population density and the ratio of university students (thousandths);

- economic indicators: the 2015 GDP value, 2016 gross salaries, and the number of vehicles per 1,000 inhabitants;

- infrastructural indicators: road density (higher-category roads - motorways, expressways, national roads, secondary roads, regional/county roads), motorway density, railway density, and ratio of air passengers in the population.

During the statistical investigation, we compared each indicator individually to the innovation index and calculated descriptive statistics, correlation, and regression. At the end of the analysis, we also did a joint regression calculation with R-program in order to investigate to what extent joint indicators account for the innovation index.

During calculations, $\mathrm{R}^{2}$ approached 0.5 in the case of three indicators: GDP, motorway density, and ratio of university students. At the end of the study, we also performed a joint regression calculation on the three most important explanatory factors: GDP, student enrolment, and the density of the expressway network. This could only be carried out for the V4 countries due to the lack of infrastructure in Romania. Based on this, the indicators examined together account for $67 \%$ of the innovation indicator: R2 is 0.67 , and p-value is negligible.

The following answers can be given to the research question:

- The Central and Eastern European countries cannot be considered a homogenous region. Within the region, very significant statistical differences can be detected both in the case of R\&D and infrastructural indicators. The performance of the V4 countries is similar to each other, whereas Romania lags far behind.

- Out of the selected innovation indicator and the nine factors examined, only three show a significant correlation (GDP, student enrolment, and the density of the expressway network); however, they do not explain the territorial pattern of innovation accurately enough. It would be worthwhile to expand the research by including additional indicators. 


\section{References}

AIRPORTS COUNCIL INTERNATIONAL. 2017. Retrieved on: 9/11/2017. https:// www.aci-europe.org/policy/position-papers.html?view=group\&group=1\&id=11.

COMMITTEE FOR INTERNATIONAL COOPERATION IN NATIONAL RESEARCH IN DEMOGRAPHY. 2017. Databases. Retrieved on: 14/11/2017. http://www. cicred.org/Eng/Publications/pdf/c-c43.pdf.

CZECH STATISTICAL OFFICE. 2017a. Public database. Retrieved on: 25/10/2017. https://www.czso.cz/csu/czso/home.

2017b. Comparison of Regions in the Czech Republic - 2017. Retrieved on: 28/10/2017. https:/www.czso.cz/csu/czso/comparison-of-regions-in-the-czechrepublic-2017.

2017c. Yearbooks. Retrieved on: 12/10/2017. https://www.czso.cz/csu/czso/ regional-yearbooks.

2017d. Population. Retrieved on: 26/10/2017. https://www.czso.cz/csu/czso/ population_hd).

DIGI24. 2017. România furată - Tarom, o companie națională lăsată în voia sorții de toate guvernările. Retrieved on: 30/10/2017. https://www.digi24.ro/stiri/ economie/transporturi/romania-furata-tarom-o-companie-nationala-lasata-invoia-sortii-de-toate-guvernarile-742377.

EUROSTAT. 2017a. Gross Domestic Product (GDP) at Current Market Prices by NUTS 3 Regions. Retrieved on: 11/11/2017. http://appsso.eurostat.ec.europa.eu/ nui/show.do?dataset=nama_10r_3gdp\&lang=en.

2017b. Number of Tertiary Education Students by Level and Sex. Retrieved on: 13/11/2017. http://ec.europa.eu/eurostat/statistics-explained/ images/8/8b/Number_of_tertiary_education_students_by_level_and_ sex\%2C_2015_\%28thousands\%29_YB17.png.

2017c. Stock of Vehicles at Regional Level. Retrieved on: 15/11/2017. http:// ec.europa.eu/eurostat/statistics-explained/index.php?title=Stock_of_vehicles_ at_regional_level\#Regional_characteristics_within_the_EU.

2017d. Products Datasets. Retrieved on: 14/11/2017. http://ec.europa.eu/ eurostat/web/products-datasets/-/ttr00002.

HUNGARIAN CENTRAL STATISTICAL OFFICE. 2017a. Public database. Retrieved on: 16/10/2017. http://www.ksh.hu/.

2017b. Magyar statisztikai évkönyv, 2016. Retrieved on: 19/10/2017. http://www. ksh.hu/apps/shop.kiadvany?p_kiadvany_id=965170\&p_temakor_kod=KSH\&p_ lang=HU.

2017c. Területi statisztikai évkönyv, 2015. Retrieved on: 17/10/2017. http://www. ksh.hu/apps/shop.kiadvany?p_kiadvany_id=502222\&p_temakor_kod=KSH\&p_ lang=HU. 
2017d. A háztartások életszínvonala, 2016. Retrieved on: : 26/10/2017. http:// www.ksh.hu/apps/shop.kiadvany?p_kiadvany_id=992842\&p_temakor_ kod=KSH\&p_lang=HU.

2017e. Kutató-fejlesztô helyek és K+F-létszám (1990-). Retrieved on: 16/10/2017. http://www.ksh.hu/docs/hun/xstadat/xstadat_eves/i_ohk002a.html.

2017f. Data of R\&D Units (2005-). Retrieved on: 14/10/2017. http://www.ksh.hu/ docs/eng/xstadat/xstadat_annual/i_ohk007b.html.

2017g. Mikrocenzus 2016. Retrieved on: 13/11/2017. https://www.ksh.hu/docs/ hun/xftp/idoszaki/mikrocenzus2016/mikrocenzus_2016_5.pdf.

KÓNYA, István. 2019. Külkereskedelem, regionális különbségek és a képzettek vándorlása. Közgazdasági szemle 66(6): 635-652.

MISZERAK, Martin. 2020. Whither Innovation in the V4? Retrieved on: 08.03.2020. https://visegradinsight.eu/whither-innovation-in-the-v4/?fbclid=IwAR03cA811 G51vtH1Xem50TYAh--lqlqTrjosats1Z8EEAnCLfHrT3vVzmD8.

NATIONAL INSTITUTE OF STATISTICS. 2017a. Public Information. Retrieved on: 10/10/2017. http://www.insse.ro/cms/.

2017b. TEMPO ONLINE Database. Retrieved on: 27/10/2017. http://statistici. insse.ro/shop/.

SEENEWS. 2017. Romania's Tarom Expects 2017 Loss of $207 \mathrm{mln}$. (45 mln Euro) Transport. Retrieved on: 2/11/2017. https://seenews.com/news/romanias-taromexpects-2017-loss-of-207-mln-lei-45-mln-euro-transport-min-589564.

STATISTICAL OFFICE OF THE SLOVAK REPUBLIC. 2017. Databases. Retrieved on: 23/10/2017. https://slovak.statistics.sk/.

STATISTICS POLAND. 2017a. Statistical Yearbook of the Republic of Poland 2017. Retrieved on: 30/10/2017. https://stat.gov.pl/en/.

2017b. Statistical Yearbook of the Regions - Poland 2017. Retrieved on: 31/10/2017. https://stat.gov.pl/en/topics/statistical-yearbooks/statisticalyearbooks/statistical-yearbook-of-the-regions-poland-2017,4,12.html\#.

2017c. Road Transport in Poland in the Years 2014, 2015. Retrieved on: 30/10/2017. https://stat.gov.pl/files/gfx/portalinformacyjny/en/defaultaktualnosci /3323/5/4/1/road_transport_in_poland_in_the_years_2014-2015.pdf.

WEF. The Global Competitiveness Report. 2019. Retrieved on: 08.03.2020 http:// www3.weforum.org/docs/WEF_TheGlobalCompetitivenessReport2019.pdf.

WORLDOMETER. 2017. Slovakian Population. Retrieved on: 10/11/2017. http:// www.worldometers.info/world-population/slovakia-population/. 


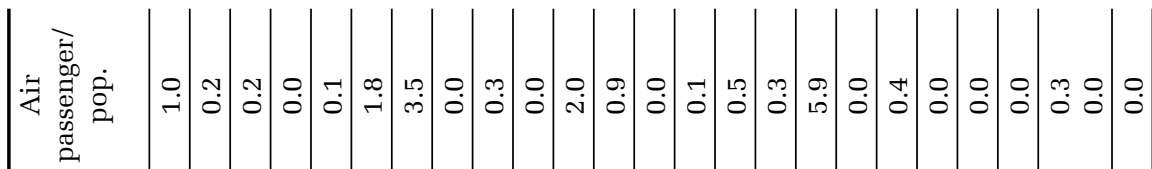

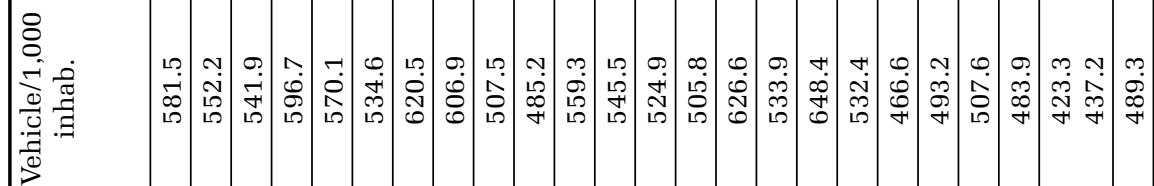

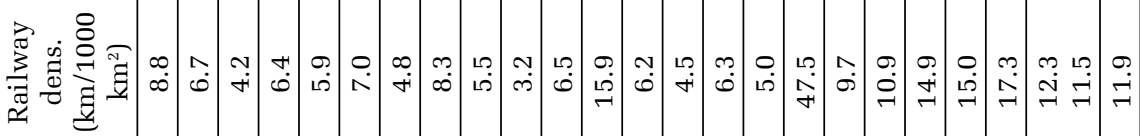

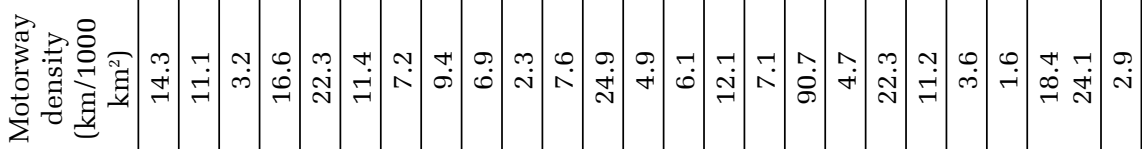

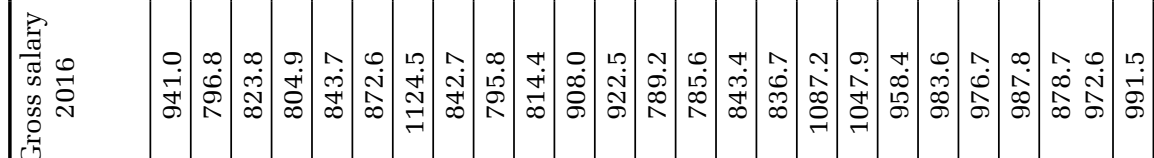

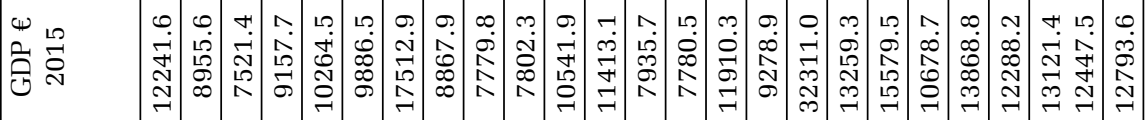

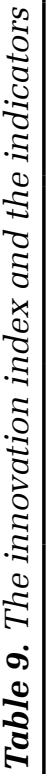
م

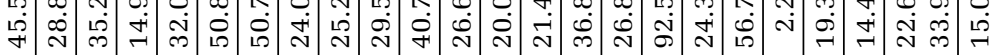

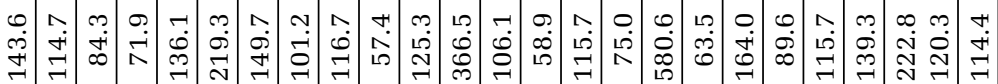
i 


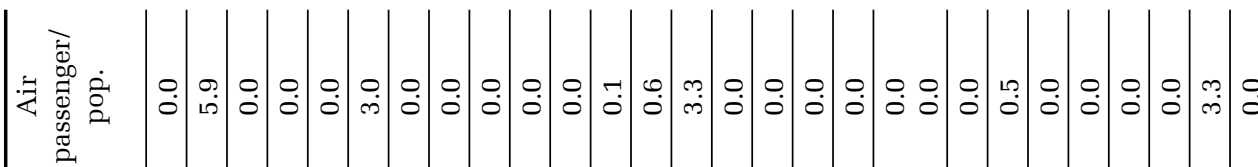
8

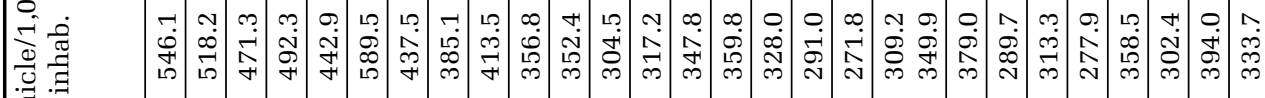

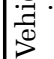

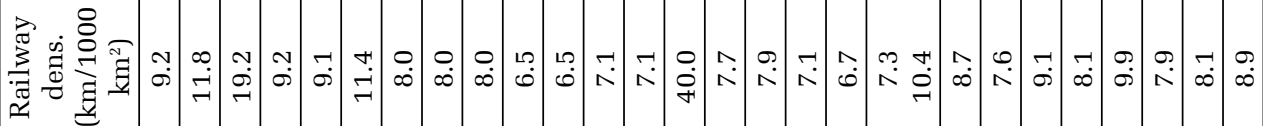

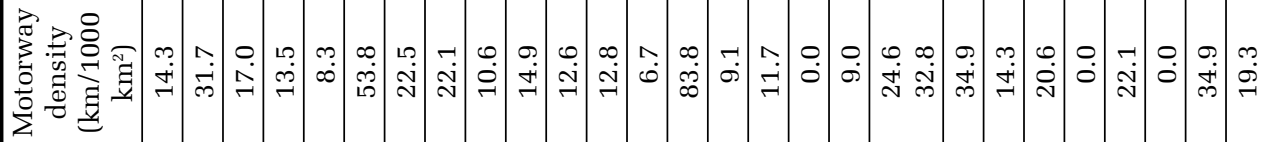

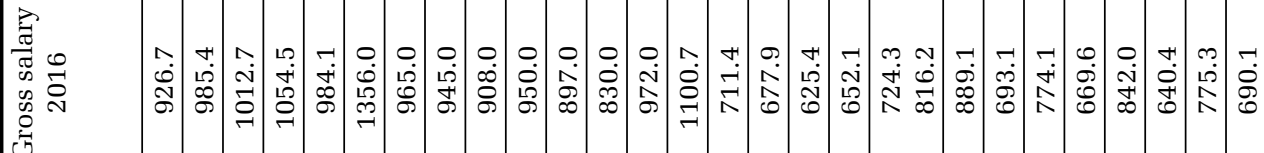

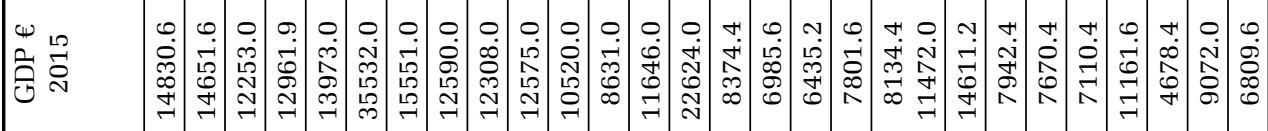

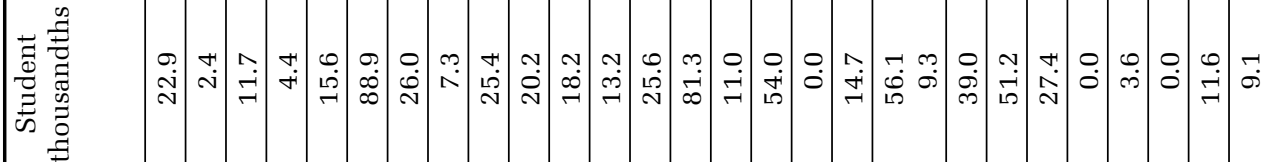

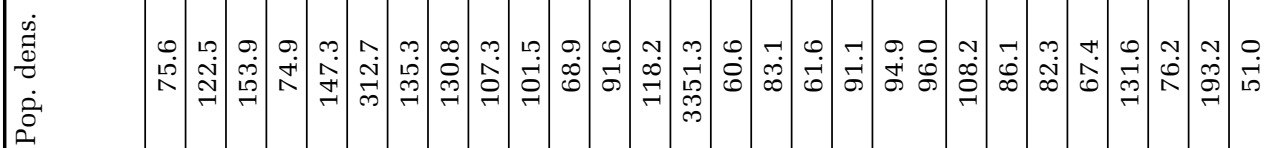

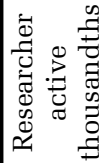

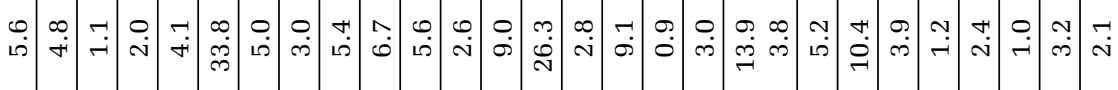

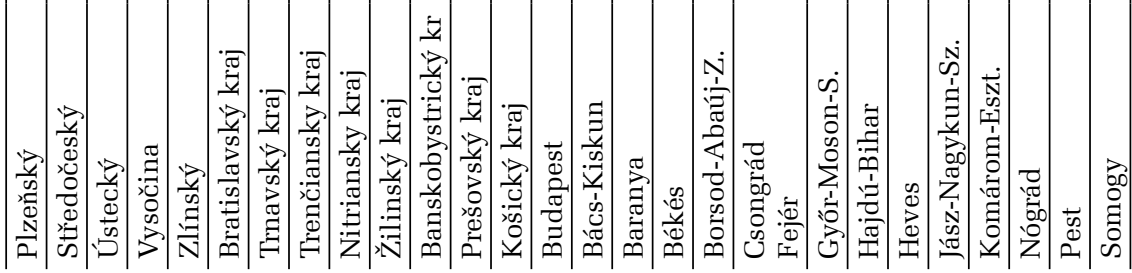




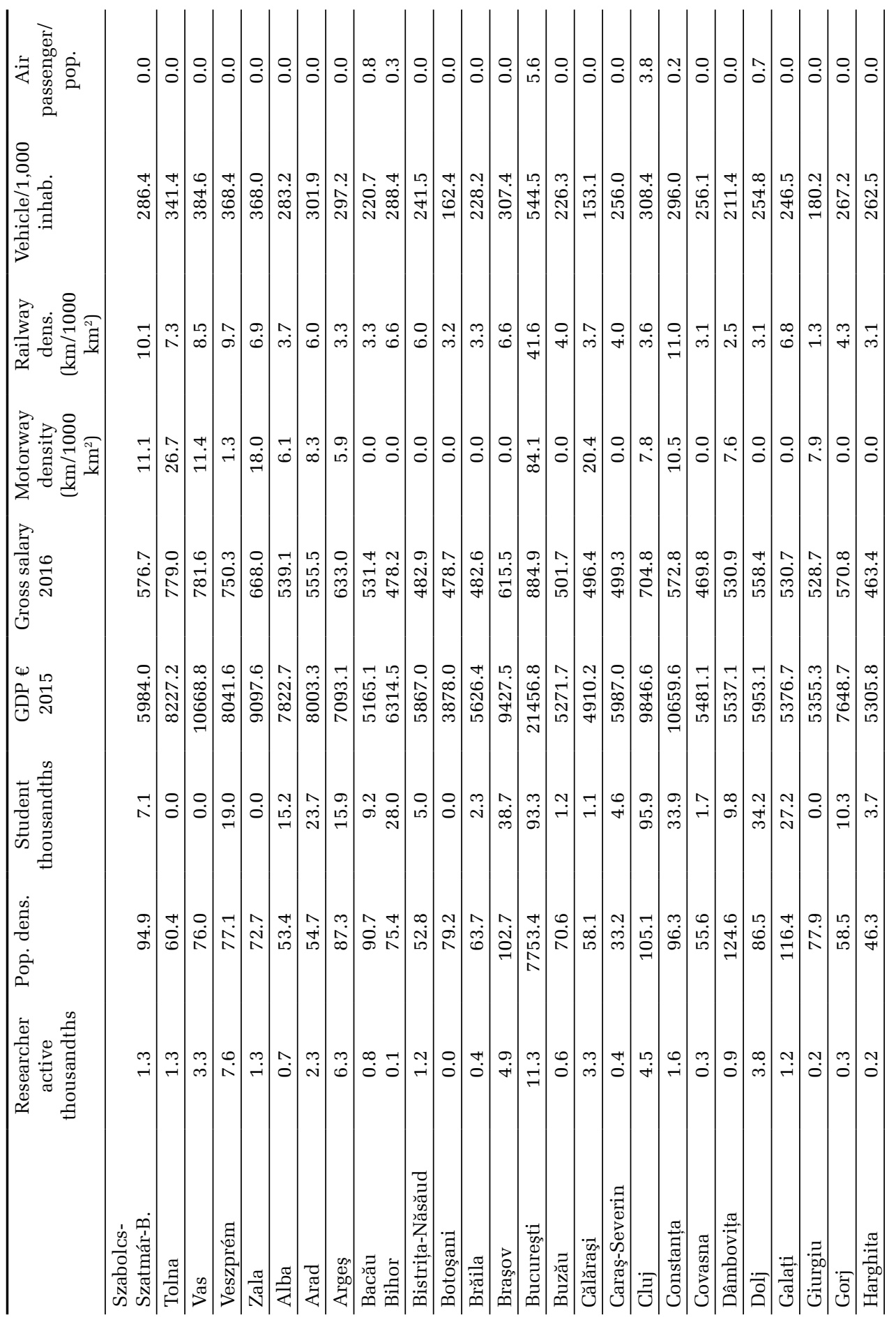




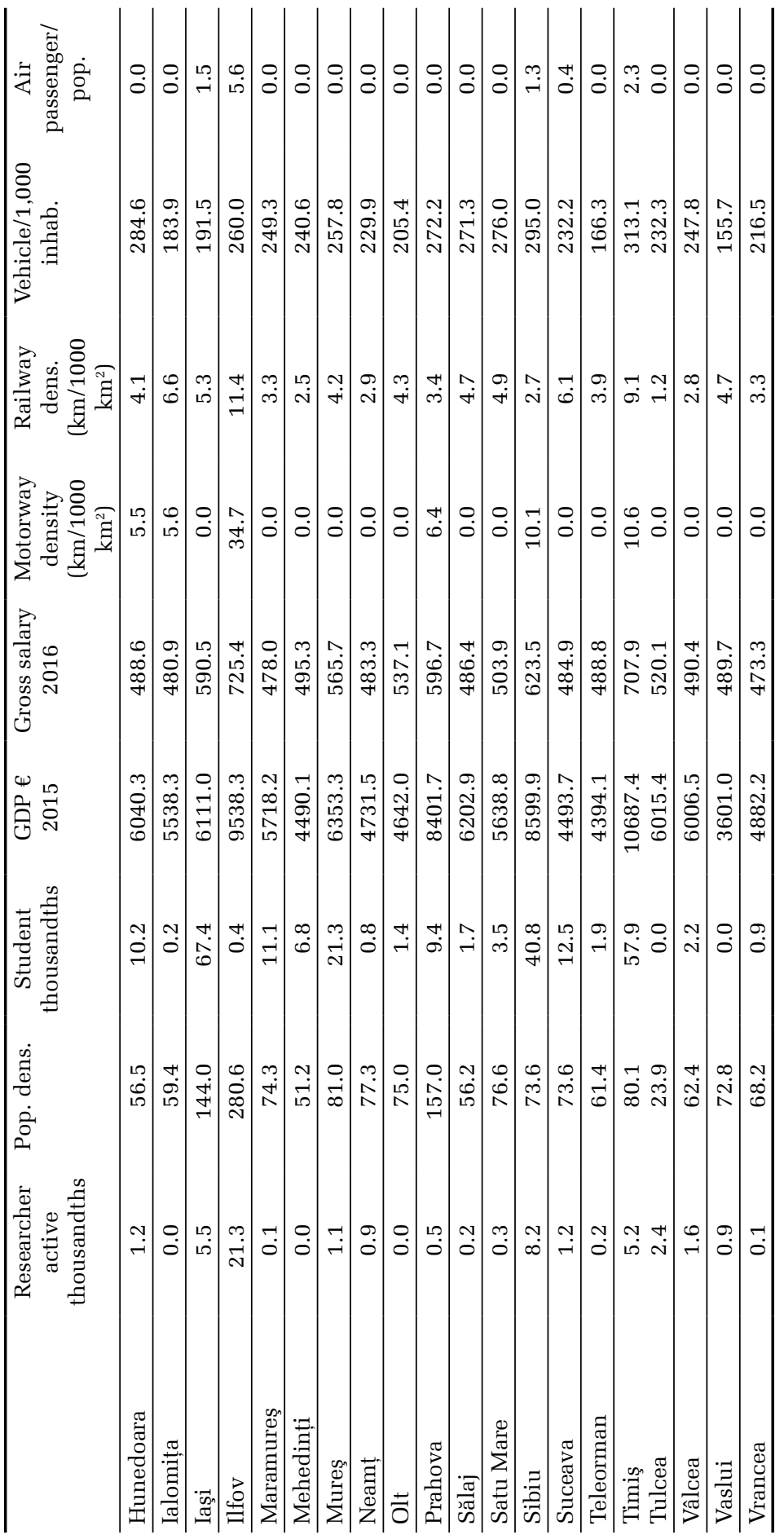

